\title{
Cancer-associated fibroblasts: an emerging target of anti-cancer immunotherapy
}

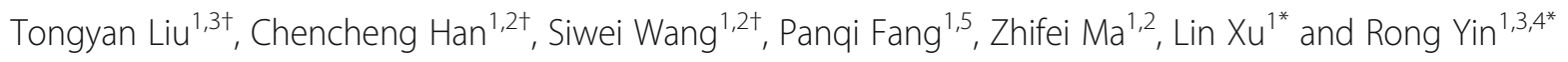

\begin{abstract}
Among all the stromal cells that present in the tumor microenvironment, cancer-associated fibroblasts (CAFs) are one of the most abundant and critical components of the tumor mesenchyme, which not only provide physical support for tumor cells but also play a key role in promoting and retarding tumorigenesis in a context-dependent manner. CAFs have also been involved in the modulation of many components of the immune system, and recent studies have revealed their roles in immune evasion and poor responses to cancer immunotherapy. In this review, we describe our current understanding of the tumorigenic significance, origin, and heterogeneity of CAFs, as well as the roles of different CAFs subtypes in distinct immune cell types. More importantly, we highlight potential therapeutic strategies that target CAFs to unleash the immune system against the tumor.
\end{abstract}

Keywords: Cancer-associated fibroblasts, Heterogeneity, Immune suppression, Cancer immunotherapy

\section{Background}

The concept of the tumor microenvironment (TME) in the initiation and progression of a multitude of malignancies has been recognized over the past decade $[1,2]$. The TME or stromal is a multicellular system composed of cells from mesenchymal, endothelial, and hematopoietic origins arranged in the extracellular matrix (ECM), which interact closely with tumor cells, contributing to tumorigenesis. The tumor-TME crosstalk regulates, either positively or negatively, cancer progression. While the TME of early-stage tumors confers anti-malignancy functions, some cancer cells can tolerate the suppression and, in turn, reprogram the TME into one exerting pro-malignancy functions [3]. Within the TME infrastructure, the secreted products of a variety of immune and non-immune cell types, such as cytokines and chemokines, and the different components such as metabolites, hypoxia, angiogenesis, ECM remodeling, interstitial pressure, and $\mathrm{pH}$ changes drive a chronic inflammatory, pro-angiogenic, and immunosuppressive intratumoral environment [4]. In the past decade, the TME

\footnotetext{
* Correspondence: xulin83cn@gmail.com; rong_yin@njmu.edu.cn

†Tongyan Liu, Chencheng Han, and Siwei Wang contributed equally to the paper.

${ }^{1}$ Department of Thoracic Surgery, Jiangsu Cancer Hospital \& Jiangsu Institute of Cancer Research \& The Affiliated Cancer Hospital of Nanjing Medical University, Jiangsu Key Laboratory of Molecular and Translational Cancer Research, Collaborative Innovation Center for Cancer Personalized Medicine, Nanjing, China

Full list of author information is available at the end of the article
}

has been admitted as a target-rich environment for developing novel anticancer agents [5].

One of the most dominant components in the tumor stroma is cancer-associated fibroblasts (CAFs), which are spindle-shaped cells that build up and remodel the extracellular matrix (ECM) structure [6]. Without question, CAFs have been extensively studied in vitro owing to their ease of isolation and inherent plasticity. However, the "CAF population" remains poorly defined in terms of their origin, subtypes, and biology due to a high heterogeneity and a lack of specific markers [7]. Recently, numerous studies have demonstrated that CAFs have emerged as important regulators of the anti-tumor immune response $[8,9]$.

Fibroblasts are generally quiescent and can be activated in a wound healing response, also known as myofibroblasts [6]. The long-held notion of tumor as "wounds that never heal" [10] indicates that CAFs could be targeted for cancer therapy. Numerous preclinical studies have indicated CAFs could be selected as an emerging target of anti-cancer immunotherapy $[6-8,10]$.

In this review, we summarize recent advances of CAF phenotypic heterogeneity and function diversity with a particular emphasis on the roles of different CAF subtypes in distinct immune cell types. We also highlight the potential therapeutic strategies targeting CAFs in the field of cancer immunotherapy. 
The significance and biological properties of CAFs The significance of CAFs in tumorigenesis

Although increasing evidence indicates that CAFs represent one of the most abundant cancer stromal cell types and contribute a lot in various malignant phenotypes, it is still necessary to fully evaluate the significance of CAFs in solid cancer malignance based on The Cancer Genomic Atlas (TCGA) dataset at first.

Pancreatic adenocarcinoma (PAAD) remains one of the most common and lethal cancers in the world. Most importantly, since infiltrated CAFs in PAAD are most abundant in all solid cancers [11], we take PAAD as an example to evaluate the relationship between CAFs and cancer malignance phenotype based on TCGA database. As shown in Fig. 1a, we found that the expression of ACTA2, fibroblast activation protein (FAP), platelet-derived growth factor receptor- $\alpha / \beta$ (PDGFR $\alpha / \beta)$, and S100A4 (widely used as markers to define CAFs) were markedly overexpressed in PAAD tissues compared with the paired normal tissues (http://gepia.cancer-pku.cn). TCGA data analysis also showed that the expression of ACTA2, FAP, and PDGFR $\alpha / \beta$ in PAAD was positively correlated with each other significantly (Fig. 1b, c), except that S100A4 did not correlate with other markers. It is possibly attributed to the expression of S100A4 by quiescent or resting fibroblasts. It is reported that S100A4 may also serve as quiescent or resting fibroblast marker, while ACTA, FAP, PDGFR $\beta$, and PDGFR $\alpha$ are predominantly expressed by CAFs [6].

Finally, although there was no direct evidence whether CAFs could induce somatic mutation and tumorigenesis, we attempted to detect the correlation between somatic mutations and CAF markers in TCGA data. Again the PAAD data demonstrated differential expression level of ACTA2 among different KRAS status (Fig. 1d, $P=0.0469$ ). However, no significant results were found of other markers and a larger sample size is possibly needed. It is proposed that CFAs in TME may play a role in selecting tumor cells with specified driver mutation [12].

Together, the above data indicate that CAFs are a unique cell population significantly infiltrating in TME and contributing to the malignant phenotype and tumorigenesis.

\section{Biological properties: CAFs vs. normal fibroblasts}

Fibroblasts in normal tissues are identified as resting mesenchymal cells embedded in physiological ECM. They can be activated to facilitate repair and regeneration during wound healing, tissue inflammation, and fibrosis. The corresponding processes in cancer development ("wound that never heals") are tumor-promoting inflammation and tumor fibrosis [6]. As such, activated fibroblasts associated with cancer have been termed as CAFs [7]. Compared with quiescent fibroblasts, CAFs are generally larger, with indented nuclei and more cytoplasm branches under light microscopy [13]. In contrast to their normal counterparts, activated CAFs exhibit enhanced proliferative and migratory properties $[7,10]$. Fibroblasts in normal tissue are commonly considered indolent with negligible metabolic and transcriptomic activity. However, CAFs are more metabolically active. The most unique feature of CAFs is their ECM production and synthetic phenotype [6]. Furthermore, CAFs can also produce many growth factors and proinflammatory cytokines, notably, transforming growth factor- $\beta$ (TGF- $\beta$ ), vascular endothelial growth factor (VEGF), interleukin-6 (IL-6), and CXC-chemokine ligand (CXCL12), to promote angiogenesis and recruit immunosuppressive cells into the TME to assist in immune evasion $[14,15]$.

\section{Heterogeneity of CAFs}

\section{Original heterogeneity}

Mounting evidence illustrates that CAFs are a heterogeneous population of cells [6]. Such heterogeneity might depend on the numerous cellular precursors of CAFs. CAFs can be recruited and activated from normal resident tissue fibroblasts $[16,17]$. Similar to fibroblasts associated with wound healing $[6,7]$, this activation is largely depended on TME stimuli, such as local hypoxia, oxidative stress, and the growth factors released from the neighboring tumor cells and infiltrating immune cells. Fundamentally, TGF- $\beta$, epidermal growth factor (EGF), platelet-derived growth factor (PDGF), and fibroblast growth factor 2 (FGF2) are key regulators of fibroblast recruitment and activation $[18,19]$. Moreover, immune cell-derived interleukin-1 $\beta$ (IL-1 $\beta$ ) triggers nuclear factor- $\mathrm{kB}(\mathrm{NF}-\mathrm{kB})$ activation in fibroblasts, involved in their education and proinflammatory secretome [20]. For example, resident fibroblast in the liver and pancreas, known as quiescent hepatic stellate cells (HSCs) and pancreatic stellate cells (PSCs), can acquire a myofibroblast-like phenotype, including $\alpha$-smooth muscle actin ( $\alpha$-SMA) expression (which considered as CAFs in liver and pancreatic cancers, respectively) upon TGF- $\beta$ and PDGF activation [21, 22]. In addition to the local sources, a portion of CAFs can transdifferentiate from non-fibroblastic lineage such as epithelial cells [23, 24], blood vessels [25], adipocytes, pericytes, and smooth muscle cells [26-28]. Generally, epithelial and endothelial cells undergo epithelial-to-mesenchymal transition (EMT) and endothelial-to-mesenchymal transition (EndMT), respectively, with an expression of S100A4 (fibroblast specific protein-1, also called FSP-1) and adopt a fibroblastic phenotype [29, 30]. Moreover, fibrocytes, a circulating mesenchymal cell population derived from monocyte precursors, may contribute to the pool of CAFs in TME, as occurs, for example in breast cancer [31]. Finally, CAFs may arise from typical bone-marrow- 


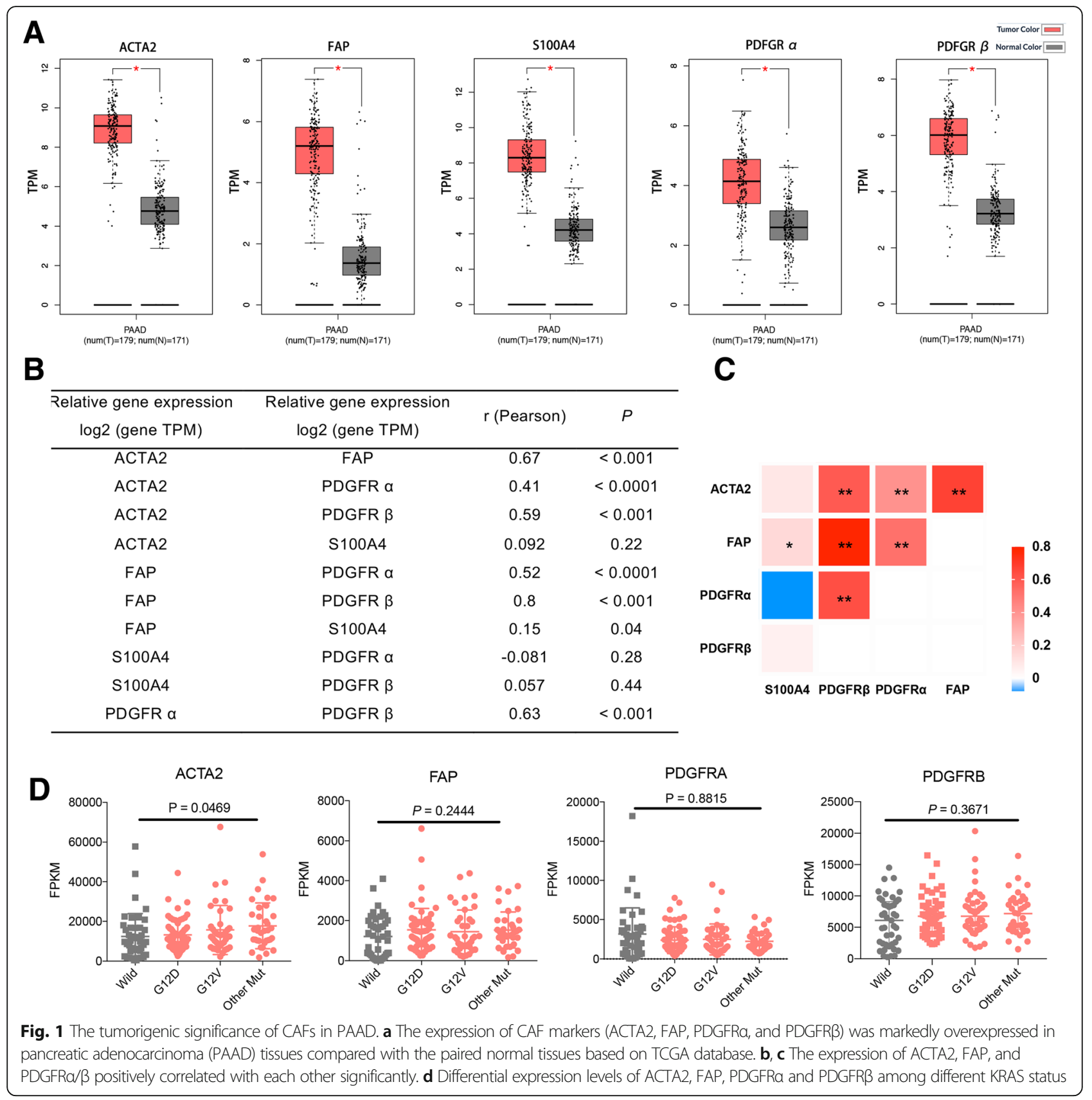

derived mesenchymal stem cells (BM-MSCs) in cancers such as glioma, breast, gastric, and pancreatic cancers [3234]. Furthermore, tumor-associated MSCs (TA-MSCs) also originate from the naive MSCs and also have the potential to differentiate into CAFs, which warrants further mechanistic studies [10] (Fig. 2).

Compared with cancer cells, CAFs are generally considered more genetically stable [35]. Nevertheless, the cytotoxic challenge-induced mutations in the normal fibroblast may contribute to the generation of CAFs [7]. Furthermore, emerging data suggests that the irreversible conversion of fibroblast into CAFs might be driven by epigenetic alteration [36-38]. Collectively, the origins of CAFs are not fully elucidated. Lineage tracing methods could be used to identify the cellular origin of CAFs and monitor the development of CAFs during cancer evolution.

\section{Phenotypic heterogeneity}

The various sources of activated fibroblasts lead to the phenotypic heterogeneity of CAFs, which can be manifested by diverse biological markers within the specific TME. Previous studies indicate that several markers, which are lower or not expressed by the normal 


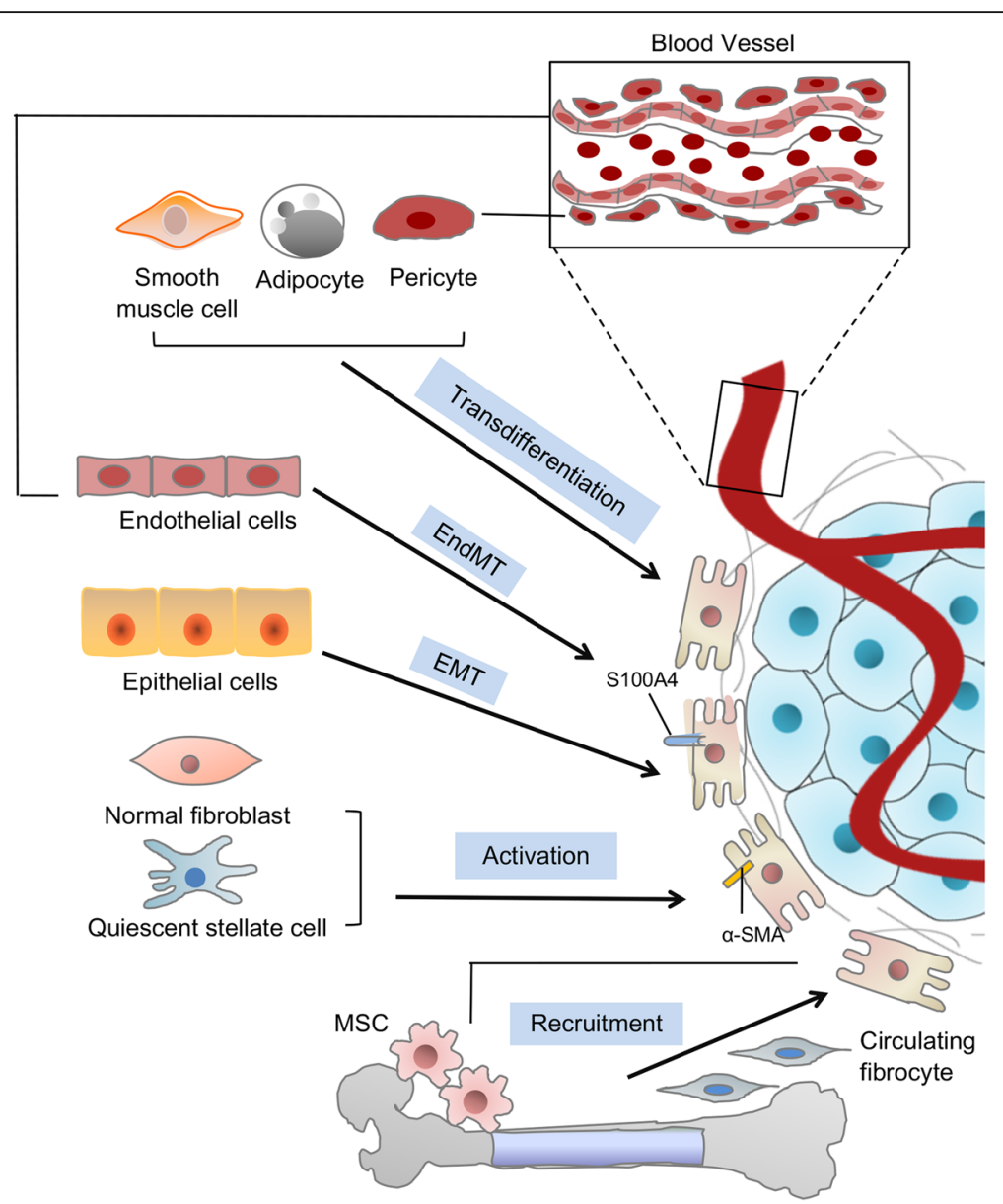

Fig. 2 Potential cellular sources of CAFs. Cancer-associated fibroblasts (CAFs) can originate from diverse cell populations. Sources of CAFs include pre-existing resident fibroblasts and stellate cells (which become CAFs through activation), epithelial cells (via epithelial-to-mesenchymal transition, EMT), endothelial cells (via endothelial-to-mesenchymal transition, EndMT), mesenchymal stem cells (MSCs), and circulating fibrocytes (via recruitment), as well as pericytes, smooth muscle cells, and adipocytes (through transdifferentiation). ECM extracellular matrix; a-SMA a-smooth muscle actin; S100A4 fibroblast specific protein-1, also called FSP-1

counterparts, can be used to detect CAFs, such as $\alpha$ SMA, S100A4, FAP, PDGFR $\alpha / \beta$, tenascin-C, neuron glial antigen (NG2), desmin, CD90/THY1, and podoplanin (PDPN) [5, 7]. However, none of these markers is exclusively expressed by CAFs, most likely highlights the heterogeneity of CAFs. Among them, $\alpha$-SMA is not only used to identify CAFs with a myofibroblast phenotype, but is also used as a general marker for vascular muscular cells and pericytes $[39,40]$. S100A4, another well-known marker, is relatively specifically found on fibroblasts [41]. FAP is also found in a subset of $\mathrm{CD} 45^{+}$immune cells [42]. PDPN also identifies lymphatic endothelial cells [43]. A recent study has identified a new CAF subset $\left(\mathrm{CD} 10^{+} \mathrm{GRP}^{+} 7^{+}\right)$associated with cancer stemness and chemoresistance [44]. In another study, Mechta-Grigoriou et al. characterize four CAF subsets in breast and ovarian cancers with distinct properties by concomitant analysis of six fibroblast markers (FAP, $\alpha$ SMA, $\beta 1 / C D 29$, S100A4, PDGFR $\beta$, and caveolin1) [45, 46].
It is worth noting that further studies using single-cell RNA sequencing (scRNA-seq) have highlighted two CAF subsets in human colorectal tumors, with CAF-A cells expressing MMP2, DCN, and COLIA2 and CAF-B cells expressing ACTA2 (encoding $\alpha$-SMA), TAGLN, and PDGFA [47]. A scRNA-seq study in patients with NSCLC shows lung tumors harbor five distinct fibroblast clusters. Remarkably, each of these fibroblast types expresses certain collagens or other extracellular matrix molecules, with for instance cluster 1 expressing COL10A1 and cluster 2 expressing COL4A1 [9]. Additionally, scRNA-seq on 768 CAFs derived from genetically engineered MMTYPyMT mice bearing breast cancer revealed four subtypes of CAFs. Notably, PDGFR $\alpha$ is specifically expressed by subtype 2, while PDGFR $\beta$ is expressed by all cells with subtype 4 excluded. FAP, S100A4, and ACTA2 are generally expressed in four populations [48].

Currently, despite the diversity of CAF markers, defining a functional population of CAFs using cell surface 
markers stays challenging. Future studies could use scRNA-seq and in vivo models to interpret the heterogeneity of CAFs in the context of cellular origin, surface marker, RNA profiles, activation stages, and spatial distributions.

\section{Functional heterogeneity}

Studies show that CAFs are composed of diverse functionally heterogeneous subpopulations that either promote or restrain cancer growth $[6,7,10]$. The pro-tumorigenic functions of CAFs have been investigated extensively based on in vitro and in vivo studies $[49,50]$. For example, $\alpha-\mathrm{SMA}^{+} \mathrm{CAFs}$ utilize the CXC-chemokine ligand 12CXC-chemokine receptor 4 (CXCL12-CXCR4) interaction to promote the proliferation of cancer stem cells [51]. Fundamentally, many other CAF-derived factors, such as matrix metallopeptidase 2 (MMP2), CXCL12, TGF- $\beta$, and IL-6, can promote the proliferation and invasion of cancer cells in various tumors [16]. However, the tumor-suppressive role of CAFs has been observed recently. For instance, the deletion of $\alpha-\mathrm{SMA}^{+}$myofibroblasts in pancreatic cancer suppresses immune surveillance by increasing $\mathrm{CD} 4^{+}$Foxp $3^{+}$regulatory $\mathrm{T}$ cells (Tregs) in tumors [52]. Similarly, the deletion of fibroblast-rich desmoplastic stroma with sonic hedgehog inhibitor in pancreatic ductal adenocarcinoma increases the aggressive of tumors [53]. Interestingly, it is reported that breast TME harbors at least two CAF types based on CD146 expression. Specifically, CD146 ${ }^{-}$CAFs suppress estrogen receptor expression and the responsiveness of cancer cells to estrogen. However, CD146 ${ }^{+}$CAF can promote tamoxifen sensitivity to the luminal breast cancer cells [54].

Overall, CAFs have been involved in tumorigenesis, angiogenesis, metastasis, immunosuppression, drug resistance, maintenance of cancer stemness, ECM remodeling, and metabolic reprogramming [6, 48]. Nonetheless, for simplicity, we will elaborate on the following parts of this review on the tumor-promoting and immunosuppressive capabilities of CAFs and the potential immunotherapy strategies targeting CAFs.

\section{CAF-related anti-tumor immune response}

\section{a-SMA ${ }^{+}$CAF-mediated immunosuppressive in TME}

$\alpha-\mathrm{SMA}^{+} \mathrm{CAFs}$, also known as myofibroblasts, contribute to an immunosuppressive TME in various ways including paracrine and ECM remodeling (Fig. 3). Tumor-associated macrophages (TAMs) are the most abundant type of innate immune or inflammatory cell in close proximity to the CAF-populated areas, indicating a close association between these two cell types. In pancreatic cancer, $\alpha-\mathrm{SMA}^{+}$vimentin ${ }^{+}$glial fibrillary acidic protein ${ }^{+}$ (GFAP), CAFs secret macrophage colony-stimulating factor 1 (M-CSF), IL-6, and CC-chemokine ligand 2 (CCL2) to promote monocyte recruitment encourage macrophage differentiation and M2 polarization [55]. The secretion of major cytokines, such as IL-6, IL-8, TGF- $\beta$, and IL- 10 by $\alpha-\mathrm{SMA}^{+}$CAFs and $\alpha-\mathrm{SMA}^{+} \mathrm{FAP}^{+}$ CAFs, also actively increases the recruitment of monocytes and their differentiation into M2 phenotype [56, 57]. Reciprocally, TAMs with a M2 phenotype further activate CAFs and thereby promote tumor progression $[58,59]$. In vitro studies show that $\alpha-\mathrm{SMA}^{+} \mathrm{FAP}^{+} \mathrm{CAFs}$ educated MSCs (CAF-like MSCs) and can promote the invasiveness of TAMs [60]. Furthermore, the expression of both CAF markers ( $\alpha$-SMA, S100A4, and FAP) and M2 macrophages markers (CD163 and DC-SIGN) is correlated with the poor clinical outcome of squamous cell carcinoma and colorectal cancer patients [61, 62]. Moreover, $\alpha-\mathrm{SMA}^{+} \mathrm{CAF}$-derived IL- 6 can recruit neutrophils, activate signal transducer and activator of Janus kinase-programmed cell death ligand 1 (STAT3-PDL1) signaling cascade in neutrophils, therefore, contributing to immunosuppression in hepatocellular carcinoma [63]. Additionally, it has been reported that HSCs can activate mast cells; reciprocally, mast cell-derived IL-13 and tryptase can then active CAFs [64]. It is worth noting that activated mast cells not only increase tumor progression but also affects tumor immunity. For example, mast cellderived IL-13 and adenosine might, respectively, promote M2 macrophage polarization and block the access of $\mathrm{CD}^{+} \mathrm{T}$ cells $[65,66]$. Mast cells can also generate the infiltration of myeloid-derived suppressor cell (MDSCs) and Tregs in the TME [67]. However, how CAF-mast cell interaction is implicated to the tumor immunity is not fully elucidated and requires further investigation. Finally, as a major source of TGF- $\beta, \alpha-\mathrm{SMA}^{+}$ CAFs can also regulate the activity of natural killer (NK) cells $[5,7]$. Multiple studies have underscored the importance of TGF- $\beta$ in suppressing NK cell activation and cytotoxic activity [68]. For example, TGF- $\beta$-induced miR-183 inhibits DAP12 transcription and decreases NK-activating receptor NKp30 and NK Group 2D (NKG2D) expression, resulting in restrained NK cytotoxicity [69]. TGF- $\beta$ can also restrict the secretion of interferon- $\gamma$ (IFN- $\gamma$ ) by NK cells, which is crucial for stimulating effector $\mathrm{CD}^{+} \mathrm{T}_{\mathrm{H}} 1$ cell-mediated antitumor reactions $[68,70]$. A recent study in melanoma has also shown $\alpha-\mathrm{SMA}^{+}$CAF-derived MMP2 may cleave two ligands of the NK-activating receptor at the surface of tumor cells and consequently reduce the NKG2D-dependent cytotoxicity against melanoma tumor cells [8].

Besides the innate immunomodulatory functions, $\alpha$ $\mathrm{SMA}^{+}$CAFs might also interfere with the adaptive immune response at different levels. $\alpha-\mathrm{SMA}^{+} \mathrm{CAF}$-derived TGF- $\beta$ and IL- 6 are implicated in restraining dendritic cells (DCs) function and maturation, disabling $\mathrm{T}$ cell activation and inducing $\mathrm{T}$ cell anergy [56, 70-72]. IL-6 


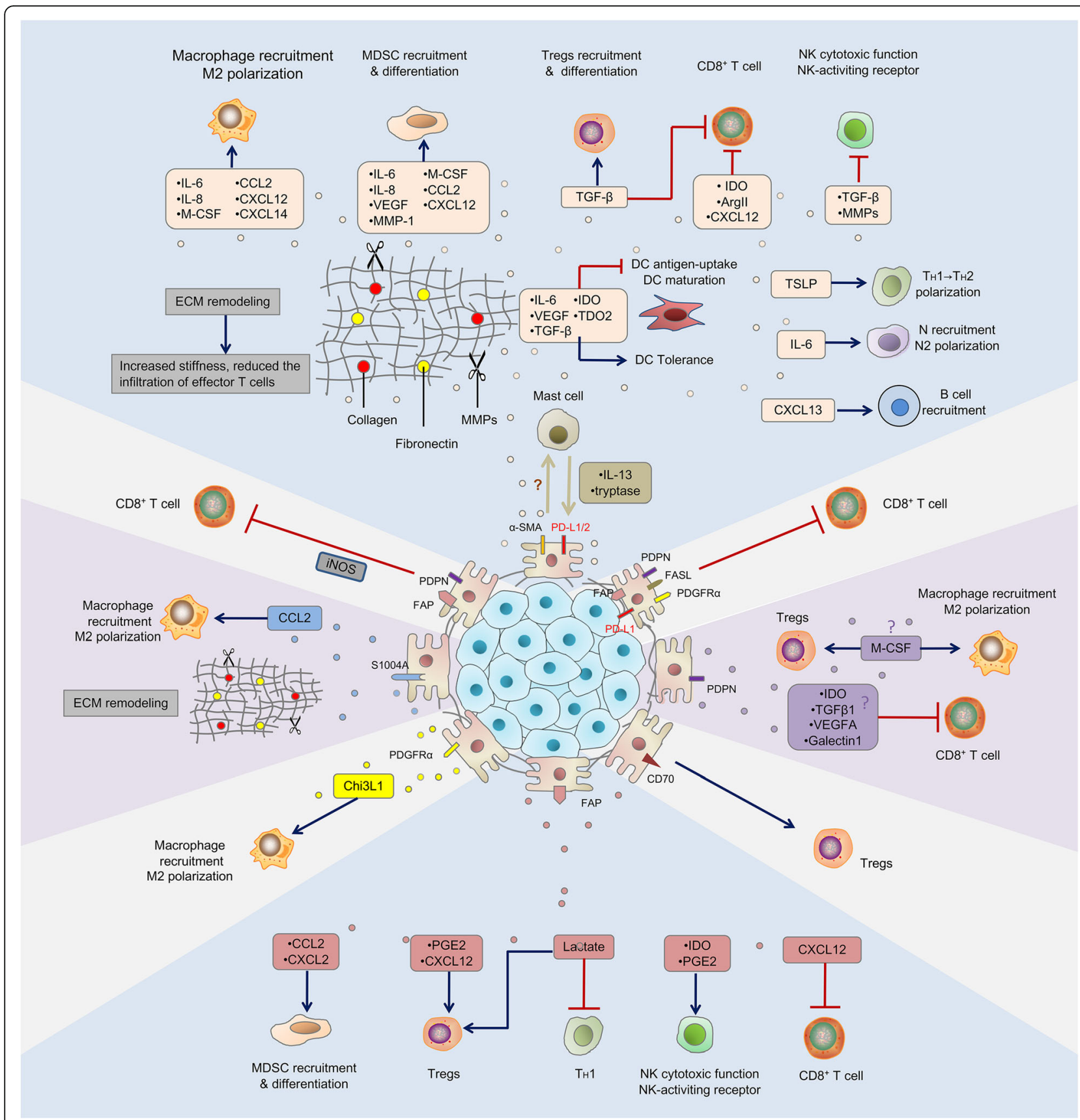

Fig. 3 Immunosuppressive functions of different CAFs subtypes. Cancer-associated fibroblasts (CAFs) orchestrate an immunosuppressive tumor microenvironment. Different CAFs subtypes secrete numerous chemokines and cytokines, such as transforming growth factor- $\beta$ (TGF- $\beta$ ), interleukin- 6 (IL-6), interleukin-8 (IL-8), interleukin-13 (IL-13), CX-chemokine ligand 12 (CXCL12), CX-chemokine ligand 14 (CXCL14), and vascular endothelial growth factor A (VEGF), thereby inhibiting both the innate and adaptive anti-tumor immune response. Of note, some subpopulations express programmed cell death 1 ligand 1/2 (PD-L1/2), a target for immune checkpoint inhibitor. Metabolites or metabolic enzymes, such as indoleamine-2,3-dioxygenase (IDO), arginase (Arg), adenosine, and tryoptase produced by certain subtypes of CAFs favor the recruitment and differentiation of regulatory T cell (Tregs), mast cells, and tumor-associated macrophages (TAMs). Finally, CAFs can synthesize the extracellular matrix (ECM) components such as collagen, fibronectin, and matrix metalloproteinases (MMPs). Multiple CAF subtypes contribute to increased ECM stiffness, which in turn reduces the infiltration of effector T cells. MDSC myeloid-derived suppressor cell, DC dendritic cell, NK natural killer cells, $T_{H}$ cells CD4 ${ }^{+}$helper lymphocytes, $N$ neutrophils, FAP fibroblast activation protein, PDPN podoplanin, CCL2 chemokine ligand 2, M-CSF macrophage colony-stimulating factor, PDGFR platelet-derived growth factor, APC antigen-processing cell, FASL FAS ligand 
signaling also redirects monocytes differentiated into macrophage rather than DCs $[6,73]$ and activates mast cells [6]. Furthermore, the tryptophan 2,3-dioxygenase (TDO2) and indoleamine-2,3-dioxygenase (IDO) released by $\alpha-\mathrm{SMA}^{+} \mathrm{CAFs}$ isolated from lung cancer enhance tryptophan degradation in kynurenines (Kyn) and consequently inhibits DCs differentiation and functions [8]. Finally, the VEGF derived from $\alpha-\mathrm{SMA}^{+} \mathrm{CAFs}$ suppresses $\mathrm{DC}$ generation and maturation $[74,75]$. The role of $\alpha$-SMA ${ }^{+}$CAFs in modulating $\mathrm{T}$ cell activity and function has also been underscored. As described above, $\alpha-$ $\mathrm{SMA}^{+}$CAFs are an important cellular source of TGF- $\beta$, which inhibits $\mathrm{CD}^{+}{ }^{+} \mathrm{T}$ cell cytotoxic function by reducing the expression of perforin, granzymes A/B, FASL (FAS ligand), and IFN- $\gamma[14,76]$. Activated PSCs (equivalent of CAFs in pancreatic cancer) secrete chemokines such as CXCL12 to sequester $\mathrm{CD}^{+}{ }^{+} \mathrm{T}$ cells from accessing tumor cells [77]. Moreover, $\alpha-\mathrm{SMA}^{+} \mathrm{FAP}^{+} \mathrm{CAFs}$ appear to inhibit the proliferation of $\mathrm{CD}^{+} \mathrm{T}$ cells and promote the recruitment of $\mathrm{CD} 4{ }^{+} \mathrm{CD} 25^{+} \mathrm{T}$ cells by secreting TGF- $\beta$ and VEGF [78]. More importantly, $\alpha-$ $\mathrm{SMA}^{+}$CAF-derived metabolic reprogramming factors, such as IDO1, Arg2, and galectin, are responsible for generating an immunosuppressive TME via inducing $\mathrm{T}$ cell anergy and inhibiting $\mathrm{CD} 8^{+} \mathrm{T}$ cell proliferation [79-81]. Additionally, in pancreatic cancer, $\alpha-\mathrm{SMA}^{+}$ CAF-released thymic stromal lymphopoietin (TSLP) has been involved in $\mathrm{T}_{\mathrm{H}} 2$ cell polarization via myeloid DC conditioning [82]. Meanwhile, TGF- $\beta$, CXCL12, and VEGF secreted by $\alpha$-SMA ${ }^{+}$CAFs can favor the recruitment and differentiation of Tregs and $\mathrm{T}_{\mathrm{H}} 17$ cells $[45,46,83-85]$. In this regard, the coexistence of FoxP3 ${ }^{+}$Tregs and CAFs predicts poor outcome in lung adenocarcinoma [83]. It has been demonstrated that PSC-derived cytokines (such as IL-6, VEGF, and M-CSF) and chemokine (such as CXCL12 and CCL2) drive monocyte precursors toward an MDSC phenotype through STAT3 activation $[8,55]$. Moreover, $\alpha-$ $\mathrm{SMA}^{+} \mathrm{CAFs}$ in $\mathrm{HCC}$ attract monocytes to the tumor stroma by the secretion of CXCL12 and facilitate their differentiation into MDSCs in a IL-6-STAT3dependent manner, thus contributing to the suppression of adaptive immune responses [86].

Interestingly, cultured $\alpha-\mathrm{SMA}^{+} \mathrm{CAFs}$ from colon tumor and melanoma carcinoma, as well as human fibroblast-specific $112 \mathrm{kDa}$ surface molecule $^{+}($Thy 1$) \alpha-$ $\mathrm{SMA}^{+} \mathrm{FAP}^{+} \mathrm{CAFs}$ from lung cancer, have been reported to express immune checkpoint molecule programmed death 1 ligand 1/2(PDL-1/2), which strongly induce $\mathrm{T}$ cell exhaustion [87-89]. Li et al. also report that $\alpha-$ $\mathrm{SMA}^{+}$CAFs were positively correlated with PD-L1 expression by tumor cells in melanoma and colorectal carcinoma. Mechanistically, CX-chemokine ligand 5 (CXCL5) derived by $\alpha$-SMA ${ }^{+}$CAFs enhances the expression of PD-L1 in tumor cells by activating PI3K/ AKT signaling pathway [90]. Finally, $\alpha-\mathrm{SMA}^{+} \mathrm{FAP}^{+} \mathrm{CAFs}$ were reported to respond to hypoxia and castrationcaused tissue damage by promoting CX-chemokine ligand 13 (CXCL13) production, which aided B cells and other immunosuppressive cell trafficking to the TME that establish tumor progression [91, 92].

CAFs may also indirectly regulate the immune response through ECM remodeling [93, 94]. The modified ECM protein network serves as a physical barrier, blocking access of immune cells to the cancer cells [93, 95, 96]. For example, aligned fibronectin and collagen modified by $\alpha-\mathrm{SMA}^{+}$CAFs associate with poor cytotoxic T cell (CTL) infiltration [97-99]. Moreover, the extensive deposition of hyaluronic acid and collagen I, which can be highly secreted by $\alpha-\mathrm{SMA}^{+}$CAFs, improves TAMs infiltration [95]. However, the effect of ECM composition on Tregs, DCs, and neutrophils remains poorly understood.

Although $\alpha-\mathrm{SMA}^{+} \mathrm{CAFs}$ have potent immunosuppressive roles, $\alpha-\mathrm{SMA}^{+}$CAFs may also associate with the activation of tumor immune response. For example, myofibroblast-depleted mice with pancreatic ductal adenocarcinoma (PDAC) showed suppressed immune surveillance with increased $\mathrm{CD}^{+}$Foxp $3^{+}$ Tregs infiltration [52]. $\alpha-\mathrm{SMA}^{+} \mathrm{S} 100 \mathrm{~A} 4^{+}$CAFs have been reported to promote $\mathrm{CD} 8^{+} \mathrm{T}$ cells activation by fusion with DCs [100]. Such disparity possibly attributed to the existence of heterogeneous CAF subsets with $\alpha$-SMA positive. Collectively, the $\alpha$-SMA ${ }^{+}$CAFs secretome might directly and indirectly regulate the anti-tumor immune response with many described and not yet elucidated manners.

\section{FAP $^{+}$CAF-mediated immunosuppressive in TME}

Among the various CAF populations, the immunosuppressive role of $\mathrm{FAP}^{+} \mathrm{CAFs}$ has been studied by different groups $[15,46,101]$ (Fig. 3). $\mathrm{FAP}^{+}$CAFs can induce monocyte recruitment and their differentiation into TAMs [8]. $\mathrm{FAP}^{+}$CAFs inhibit the anti-tumor effect of M-CSF blockade by upregulating the infiltration of polymorphonuclear MDSCs in the TME [102]. Moreover, elevated FAP expression by CAFs can also recruit the circulating MDSCs into the tumor stroma through uPAR-FAK-DRC-JAK2-STAT3-CCL2 signaling pathway, thus resulting in immunosuppression in hepatic cancer [101]. Furthermore, in melanoma, hepatocellular, and colorectal carcinoma, $\mathrm{FAP}^{+} \mathrm{CAFs}$-derived prostaglandin (PGE2) and IDO can reduce the expression of NK-activating receptors, perforin and granzyme $\mathrm{B}$, therefore, inhibit NK cell cytotoxicity and cytokine production [103]. As a principle source of CXCL12, $\mathrm{FAP}^{+}$CAFs also use the CXCL12-CXCR4 interaction to inhibit the infiltration of $\mathrm{T}$ cells in PDAC and lung carcinoma bearing 
mice $[15,93,104]$. In this context, the blockade of CXCL12-CXCR4 axis improves sensitivity to checkpoint blockade therapy [15]. Consistent with this finding, Mechta-Grigoriou et al. have identified four subtypes of cancer-associated fibroblasts (CAF-S1-4) in human breast cancer and high-grade serous ovarian cancers by fluorescent-activated cell sorting, and found CAF-S1 subtype, characterized by elevated FAP expression, which is responsible for generating an immunosuppressive TME by accumulating $\mathrm{CD} 4^{+} \mathrm{CD} 25^{+} \mathrm{T}$ cells and enhancing their differentiation to Tregs $[45,46]$. CCchemokine ligand 5 (CCL5) production by $\mathrm{FAP}^{+} \alpha-\mathrm{SMA}^{+}$ CAFs in mammary carcinoma has appeared to preferentially recruit Tregs, owing to the highly expressed CCchemokine receptor 1 (CCR1) by Tregs $[5,105]$. A recent study also reveals that $\mathrm{FAP}^{+} \mathrm{PDPN}^{+}$CAFs could regulate tumor-specific cytotoxic cell motility and localization through nitric oxide synthase (iNOS) [106]. Furthermore, in a prostate cancer model, $\mathrm{FAP}^{+} \mathrm{CAF}$-derived lactate is associated with increased Tregs and a shift in the polarization of $\mathrm{CD} 4^{+} \mathrm{T}$ cells from $\mathrm{T}_{\mathrm{H}} 2$ to $\mathrm{T}_{\mathrm{H}} 1$ phenotype, which depends on NF-kB signaling and FoxP3 expression [107]. In addition to the direct regulation of immune cell infiltration into the TME, $\mathrm{FAP}^{+}$ CAFs may also have a pivotal role in ECM remodeling; for example, FAP + CAFs can produce TGF- $\beta$, VEGF, and multiple matrix processing enzymes $[8,10]$, indirectly disrupting the infiltration of cytotoxic $\mathrm{T}$ cells into the tumor nest.

Generally, $\mathrm{FAP}^{+} \mathrm{CAFs}$ present a significant source of distinct chemokines and cytokines that can shape the immune landscape in the TME. Further research is required to elucidate how $\mathrm{FAP}^{+} \mathrm{CAFs}$ participate in tumor immunosurveillance.

\section{Other subtypes of CAF-mediated regulation of tumor immunity}

PDGFR $\alpha / \beta$, S100A4, THY1 (CD90), and PDPN may also serve as marker sets to define CAFs. For example, Sugimoto et al. demonstrate that S100A4 identifies a unique subset of fibroblasts with minimal overlap with $\alpha$-SMA, PDGFR $\beta$, and chondroitin sulfate proteoglycan (NG2). Additionally, $\alpha$-SMA, PDGFR $\beta$, and NG2 could identify a mixed subtype of fibroblasts [108].

The immunomodulatory effects of PDGFR $\alpha / \beta^{+}$CAFs and other subtypes have also been validated in multiple studies (Fig. 3). For instance, Chitinase-3-like-1 (Chi3L1), a secreted glycoprotein involved in chronic inflammatory and fibrotic disorders, has been linked to PDGFR $\alpha^{+}$CAF-induced macrophage migration and their polarization into M2 phenotype [109]. S100A4 ${ }^{+}$CAF-derived CCL2 contributes to immune evasion by increasing the mobility and retention of macrophages [110]. Moreover, PDGFR $\beta^{+} \mathrm{PDPN}^{+} \mathrm{FAP}-\alpha^{+}$cells expressing FASL and PD-L2 induce the apoptosis of FAS-expressing $\mathrm{CD}^{+} \mathrm{T}$ cells and $\mathrm{T}$ cell anergy [111]. A recent study in stage I lung carcinoma has unveiled the role that PDPN ${ }^{+}$ CAFs have in attenuating anti-tumor immunity by decreasing the CD8/Foxp3 T cell ration, supporting monocyte recruitment and their differentiation into TAMs [112]. In vitro studies show $\mathrm{CD}^{+}{ }^{+} \mathrm{CAFs}$ isolated from invasive colorectal cancer specimens stimulate the migration of Tregs. Meanwhile, the expression of CD70 on CAFs is proved to be an independent adverse prognostic marker for colorectal cancer [113]. Bone marrowderived CAFs can also inhibit allogeneic $\mathrm{T}$ cell responses through IDO production [114]. Furthermore, collagen $\mathrm{I}^{+}$ CAFs increase TAMs trafficking to the stromal areas via hyaluronan-mediated ECM remodeling, thereby suppressing anti-tumor immunity [115]. Interestingly, S100A4-expressing CAFs may also increase immune surveillance ability through collagen production and encapsulation of carcinogens [41].

Although there has been increasing interest in cancer immunology, we are still beginning to understand the roles of CAF subtypes in tumor immunosurveillance. A brief summary of the features of representative CAF types including cell surface markers, cell origins, immune functions, and tumorigenic functions is listed in Table 1. Further studies are required to establish a deeper understanding of CAF heterogeneity and immunosurveillance.

\section{CAFs is a novel target in anti-tumor immunotherapy}

The anti-tumor immunity that CAFs exert during cancer progression makes them promising therapeutic targets for cancer intervention. In the past few years, there has been considerable interest in developing "anti-CAF"based immunotherapeutic approaches. Few of them have moved into the clinic; however, some CAF-related immunotherapy is in progress (Fig. 4).

Recently, anti-CAF therapies have been primarily focused on FAP [8]. Genetic deletion of FAP leads to a marked reduction in $\mathrm{FAP}^{+} \mathrm{CAF}$ infiltration and rapid hypoxic necrosis of tumor and is associated with increased $\mathrm{CD}^{+} \mathrm{T}$ cells infiltration in Lewis lung carcinoma and PDAC models $[116,117]$. Elimination of $\mathrm{FAP}^{+}$CAFs by DNA vaccination and chimeric antigen receptor (CAR) T cells has emerged as important complements to other immunotherapeutic approaches. A pioneer study has shown oral administration of DNA-based FAP vaccine-induced $\mathrm{CD}^{+} \mathrm{T}$ cell-dependent killing of CAFs, which substantially increase the intratumoral uptake of chemotherapeutic drugs in multi-drug-resistant murine colon and breast carcinoma [118]. The development of a modified FAP DNA vaccine is capable of overcoming immune tolerance and inducing both $\mathrm{CD} 8^{+}$and $\mathrm{CD} 4^{+}$immune responses. 
Table 1 Commonly used CAF markers, their cellular origins and functions

\begin{tabular}{|c|c|c|c|c|}
\hline Marker & Cell origins & Immune functions & Tumorigenic functions & Refs \\
\hline a-SMA & $\begin{array}{l}\text { Normal fibroblasts, } \\
\text { quiescent stellate cells }\end{array}$ & $\begin{array}{l}\text { Macrophage recruitment and M2 polarization, } \\
\text { MDSCs and Tregs recruitment and differentiation, } \\
\mathrm{T} \text { cell anergy, NK cell inactivation, DCs tolerance } \\
\text { and immaturation, } \mathrm{TH}_{2} \text { and } \mathrm{N} 2 \text { polarization }\end{array}$ & $\begin{array}{l}\text { Immuno-suppression, ECM remodeling, } \\
\text { tumor cell proliferation, metabolic } \\
\text { reprogramming, cancer stemness }\end{array}$ & {$[5,7,8,49-90]$} \\
\hline FAP & $\begin{array}{l}\text { Normal fibroblasts, } \\
\text { quiescent stellate cells }\end{array}$ & $\begin{array}{l}\text { T cell anergy, NK cells inactivation, } \mathrm{TH}_{2} \text { polarization, } \\
\text { MDSCs and Tregs recruitment }\end{array}$ & $\begin{array}{l}\text { Immuno-suppression, ECM remodeling, } \\
\text { tumor progression and metastasis }\end{array}$ & $\begin{array}{l}{[8,10,40,41} \\
97-103]\end{array}$ \\
\hline S100A4 & $\begin{array}{l}\text { Epithelial cells, } \\
\text { endothelial cells }\end{array}$ & Macrophage recruitment and M2 polarization & $\begin{array}{l}\text { Immuno-suppression, ECM remodeling, } \\
\text { carcinogenesis }\end{array}$ & {$[106]$} \\
\hline PDGFRa/ $\beta$ & $\begin{array}{l}\text { Normal fibroblasts, } \\
\text { BMSCs, pericytes, vascular } \\
\text { smooth muscular cells }\end{array}$ & T cell anergy and apoptosis & Immuno-suppression, tumor growth & {$[105]$} \\
\hline PDPN & Epithelial cells & $\begin{array}{l}\text { T cell anergy, macrophage recruitment and } \mathrm{M} 2 \\
\text { polarization, Tregs recruitment }\end{array}$ & Immuno-suppression, tumor growth & {$[107,108]$} \\
\hline CD90 & & T cell exhaustion & $\begin{array}{l}\text { Immuno-suppression, tumor cell } \\
\text { migration }\end{array}$ & {$[83,84]$} \\
\hline Collagen I & $\begin{array}{l}\text { Fibroblasts, vascular } \\
\text { smooth muscular cells }\end{array}$ & Macrophage recruitment and M2 polarization & $\begin{array}{l}\text { Immuno-suppression, ECM remodeling, } \\
\text { angiogenesis }\end{array}$ & [1111] \\
\hline
\end{tabular}

a-SMA a-smooth muscle actin. FAP fibroblast activation protein, PDGFRa/ $\beta$ platelet derived growth factor receptor- $\alpha / \beta, P D P N$ podoplanin, MDSCs myeloid-derived suppressor cell, Tregs regulatory T cell, NK cells natural killer cells, N2 type2 neutrophils, DC dendritic cell, ECM extracellular matrix

The modified SynCon FAP DNA vaccine can synergize with other tumor antigen-specific vaccine therapies in tumor-bearing mice [104]. Of note, FAP-specific CAR T cell treatment in an immunocompetent mouse model has shown to boost host immunity. Similarly, co-introduction of anti-FAP and anti-tumor CAR $\mathrm{T}$ cells has also shown to enhance anti-tumor immunity in xenografted immunodeficient mouse models $[119,120]$. Additionally, the adoptive transfer of FAP-specific CAR T cells can arrest pancreatic cancer growth with low immunogenicity and high desmoplasia [121]. Recently, oncolytic adenovirus with a FAP-targeting has displayed an improved antitumor immunity through endogenous $\mathrm{T}$ cell activation to attack $\mathrm{FAP}^{+}$stromal cells in tumor-bearing mice models $[122,123]$. However, it is important to note that BMMSCs or skeletal muscles that express FAP may also be recognized and killed by FAP-reactive CAR $\mathrm{T}$ cells. As such, a contrasting result came from another study, in which adoptive transfer of FAP-reactive CAR-T cells not only had limited anti-tumor effects, but also had induced significant lethal toxicity and cachexia [116, 124]. These contrary results may attribute to the differential singlechain variable fragments (scFvs) constructed in the CARs; therefore, using FAP as a universal immunotherapy target should still be studied, albeit cautiously.

As discussed above, $\alpha$-SMA identified at least the myofibroblast population of CAFs. In a mouse model of breast cancer, docetaxel conjugate nanoparticles that target $\alpha-\mathrm{SMA}^{+}$stromal suppressed metastases [125]. Selective depletion of myofibroblasts attenuated angiogenesis in spontaneous PDAC mouse models [126]. However, targeting $\alpha$-SMA might increase the immunosuppressive $\mathrm{CD}^{+}{ }^{+} \mathrm{Foxp}^{+}{ }^{+}$Tregs infiltrate in the TME, which ultimately led to aggressive tumor development [126].

Neither $\alpha$-SMA nor FAP is exclusively expressed by CAFs, which substantially hinder the precision strategy of CAF-based therapy. In this scenario, targeting the cellular origins of CAFs may be another way to reduce CAF infiltration in the TME. A highly anticipated phase III clinical trial is ongoing to target the CAFs with endothelial cells precursors with bevacizumab [127].

In addition to the direct depletion of CAFs, it is also appealing to revert the CAF "state" by targeting the CAF activation pathways. In this context, CAF reprogramming by vitamin $\mathrm{D}$ and vitamin $\mathrm{A}$, which reset the activated state of the pro-tumorigenic CAFs to a quiescent state, has attracted much attention in PDAC and colon cancer [128-130]. Administration of pleiotropic agent all-trans retinoic acid (ATRA) inhibits tumor-promoting signaling in activated PSCs, resulting in significantly increased infiltration of $\mathrm{CD}^{+} \mathrm{T}$ cells and improved therapeutic efficacy in PDAC models [131]. In a parallel study, the stimulation of the vitamin D receptor (VDR) successfully inactivates PSCs [132]. Notably, a phase II clinical trial is now underway with concomitant treatment with PD-1 inhibitor and vitamin D analog in PDAC [10].

Investigators are also targeting CAF-derived cytokines and chemokines in combination with immunotherapies in an attempt to improve anticancer efficiency $[8,10]$. For example, a recent publication demonstrates that targeting the CXCL12-CXCR4 axis with AMD3100 (Plerixafor) reverses $\mathrm{FAP}^{+} \mathrm{CAF}$-mediated immunosuppression and synergizes with anti-PD-L1 immunotherapy in pancreatic cancer [15]. Similarly, other proteins released by CAFs, 


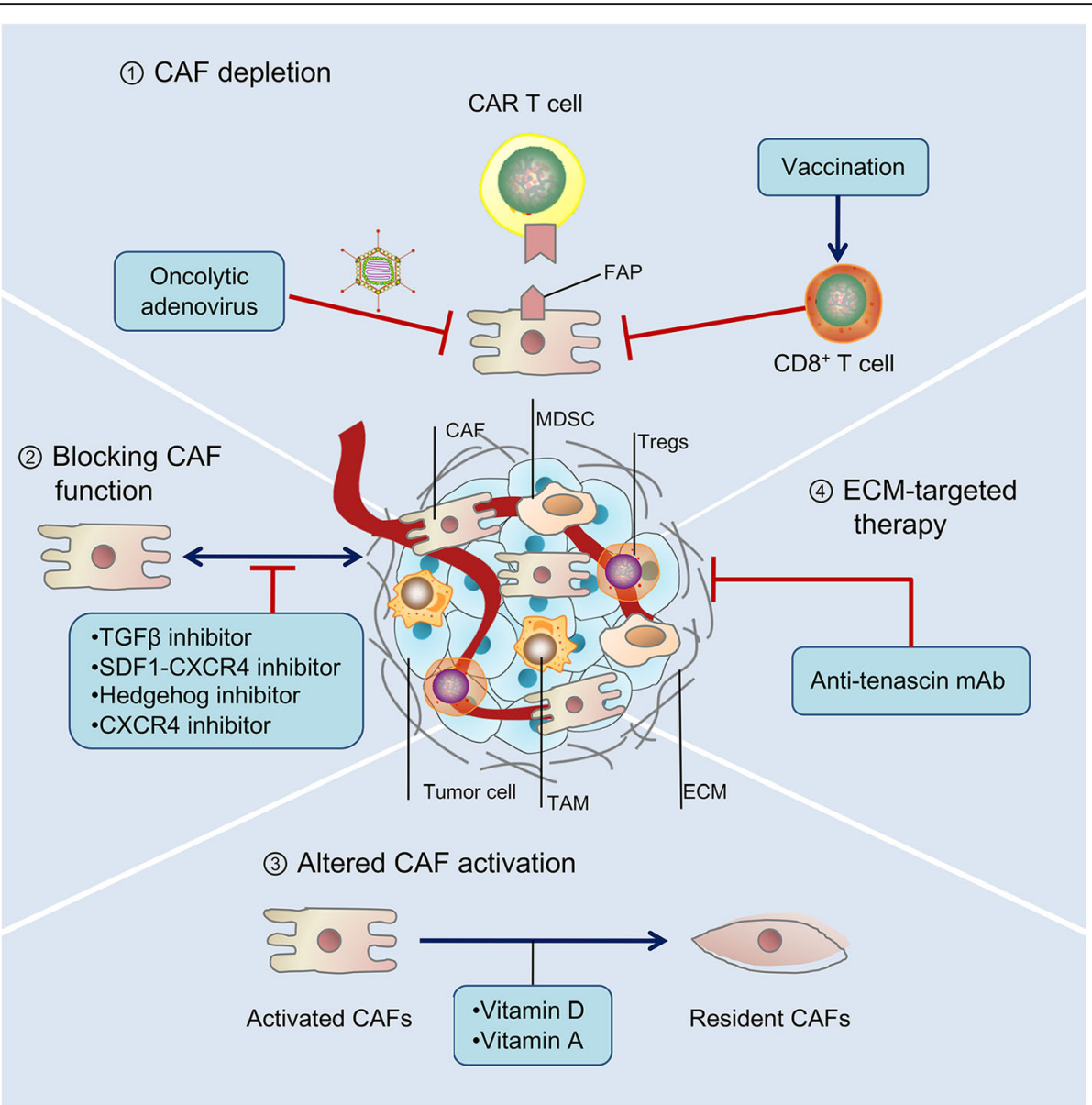

Fig. 4 Immunotherapies that target CAFs. Four general approaches that target cancer-associated fibroblasts (CAFs) for cancer immunotherapy. (1) Fibroblast activation protein ${ }^{+}\left(\mathrm{FAP}^{+}\right)$CAFs can be directly eliminated by transgenic technologies, immunotherapies, and oncolytic adenovirus. (2) Targeting the important signals and effectors of CAFs, such as CX-chemokine ligand 12-CX chemokine receptor 4 (CXCL12-CXCR4) interaction, Janus kinase-signal transducer and activator of transcription 3 (JAK-STAT3) pathway, transforming growth factor- $\beta$ (TGF- $\beta$ ), and Hedgehog signaling pathway, can be used to inhibit the function of CAFs. (3) A reprogramming strategy such as vitamin A and vitamin D can be adopted to dedifferentiate activated CAFs to resident (normalized) fibroblasts. (4) CAF-derived extracellular matrix (ECM) proteins and associated signaling pathway can be targeted to induce stromal depletion. CAR chimeric antigen receptor, mAb monoclonal antibody, MDSC myeloid-derived suppressor cell, TAM tumor-associated macrophage, Treg cell regulatory $T$ cell

such as IL- 6 and TGF- $\beta$, could also be targeted in order to improve the anti-tumor immune response [133]. For example, inhibitors of IL-6, IL-6 receptor, or Janus kinase (JAK) have already been approved by the US Food and Drug Administration for the treatment of myeloproliferative diseases and autoimmune disorders, with trials underway in cancer [134]. Novel agents that target IL-6 and its signaling pathway, including ROCKs and STAT3, have undergone clinical or preclinical trials in cancer [134]. Furthermore, TGF- $\beta$ signaling in fibroblasts is shown to attenuate tumor response to anti-PD-L1 agent by contributing to $\mathrm{T}$ cell exclusion. Therapeutic co-administration of TGF- $\beta$-blocking and anti-PD-L1 antibodies inhibit TGF- $\beta$ signaling in CAFs, facilitated $\mathrm{T}$ cell penetration into the tumor nest, and, therefore, provoke effective anti-tumor immunity and tumor regression [135, 136].
Tranilast (Rizaben), which suppresses fibroblast growth and TGF- $\beta$ secretion, synergistically enhances the effect of dendritic cell-based vaccines in C57BL/6 mice with E-G7 lymphoma, LLC1 Lewis lung cancer, or B16F1 melanoma [137]. Notably, multiple phase I clinical trials of TGF- $\beta$ based immunotherapies are ongoing, highlighting the clinical importance of stroma-based immunotherapy [68]. Investigators are also using tenascin $\mathrm{C}$ inhibitor $\left({ }^{131} \mathrm{I}\right.$ m81C6) or Hedgehog inhibitors in combination with immunotherapies and standard chemotherapies in order to ameliorate ECM stiffness to favor drug delivery $[138,139]$.

Overall, drugs that target CAFs have emerged as a critical complement to immunotherapies in multiple solid tumors. A brief summary of immunotherapeutic strategies that target CAFs in clinical and preclinical studies is given in Table 2. More specific molecular targets that 
Table 2 Immunotherapeutic strategies that target CAFs in clinical and/or preclinical studies

\begin{tabular}{|c|c|c|c|c|c|c|}
\hline Drugs & Mechanisms & $\begin{array}{l}\text { Combination } \\
\text { therapy }\end{array}$ & Biological effects & Cancer models & Status & Refs \\
\hline $\begin{array}{l}\text { SynCon DNA } \\
\text { vaccine }\end{array}$ & FAP deletion & $\begin{array}{l}\text { Anti-tumor } \\
\text { vaccine }\end{array}$ & Overcomes immune tolerance & Lung cancer & Preclinical & {$[100]$} \\
\hline $\begin{array}{l}\text { FAP-specific } \\
\text { CAR T cell }\end{array}$ & FAP deletion & $\begin{array}{l}\text { Anti-tumor } \\
\text { CAR T cell }\end{array}$ & Enhances anti-tumor immunity & Lung cancer & Preclinical & [116] \\
\hline $\begin{array}{l}\text { Oncolytic } \\
\text { adenovirus }\end{array}$ & FAP deletion & No & Enhances anti-tumor immunity & CRC & Preclinical & $\begin{array}{l}{[118,} \\
119]\end{array}$ \\
\hline $\begin{array}{l}\text { ATAR (vitamin } \\
\text { A analog) }\end{array}$ & $\begin{array}{l}\text { Vitamin A storage } \\
\text { and PSC deactivation }\end{array}$ & Gemcitabine & $\begin{array}{l}\text { Enhances anti-tumor immunity; } \\
\text { inhibits tumor cell growth }\end{array}$ & PDAC & Preclinical & [126] \\
\hline $\begin{array}{l}\text { Calcipotriol } \\
\text { (vitamin D } \\
\text { analog) }\end{array}$ & $\begin{array}{l}\text { Vitamin D receptor } \\
\text { activation and PSC } \\
\text { deactivation }\end{array}$ & $\begin{array}{l}\text { Anti-PD-1 } \\
\text { immunotherapy }\end{array}$ & $\begin{array}{l}\text { Reverses tumor } \\
\text { immunosuppression }\end{array}$ & PDAC & Phase II & [10] \\
\hline AMD3100 & $\begin{array}{l}\text { Blocks the CXCL12-CXCR4 } \\
\text { interaction }\end{array}$ & $\begin{array}{l}\text { Anti-PD-L1 } \\
\text { immunotherapy }\end{array}$ & $\begin{array}{l}\text { Reverses tumor } \\
\text { immunosuppression }\end{array}$ & PDAC & Preclinical & [96] \\
\hline $\begin{array}{l}{ }^{131} \text { I-m81C6 (anti- } \\
\text { tenascin mAb) }\end{array}$ & Radioimmunotherapy & No & $\begin{array}{l}\text { Reverses tumor } \\
\text { immunosuppression }\end{array}$ & $\begin{array}{l}\text { Recurrent malignant } \\
\text { glioma }\end{array}$ & Phase II & {$[135]$} \\
\hline $\begin{array}{l}\text { Ruxolitinib (JAK } \\
\text { inhibitor) }\end{array}$ & $\begin{array}{l}\text { JAK-STA3 pathway } \\
\text { inhibition }\end{array}$ & Capecitabine & $\begin{array}{l}\text { Inhibits tumor-promoting } \\
\text { inflammation }\end{array}$ & $\begin{array}{l}\text { Metastatic pancreatic } \\
\text { cancer }\end{array}$ & Phase II & [129] \\
\hline IPI-926 & $\begin{array}{l}\text { Hedgehog pathway } \\
\text { inhibition }\end{array}$ & Gemcitabine & $\begin{array}{l}\text { Reverses tumor } \\
\text { immunosuppression }\end{array}$ & PDAC & Preclinical & [133] \\
\hline NIS793 ABBV151 & $\begin{array}{l}\text { Blocking pan-TGF- } \beta \\
\text { and GARP }\end{array}$ & $\begin{array}{l}\text { Anti-PD-1 } \\
\text { immunotherapy }\end{array}$ & $\begin{array}{l}\text { Reverses tumor } \\
\text { immunosuppression }\end{array}$ & $\begin{array}{l}\text { Breast, lung, HCC, CRC, } \\
\text { pancreatic and renal cancer }\end{array}$ & Phase I & {$[62]$} \\
\hline
\end{tabular}

FAP fibroblast activation protein, CAR chimeric antigen receptor, ATRA all-trans retinoic acid, CXCL12 CXC-chemokine ligand 12, CXCR4 CXC-chemokine receptor 4, $P D-1$ programmed cell death-1, PD-L1 programmed cell death 1 ligand, JAK Janus kinase, STAT3 signal transducer and activator of transcription 3 , mAb monoclonal antibody, PSC pancreatic stellate cell, TGF- $\beta$ transforming growth factor- $\beta$, GARP glycoprotein A repetitions predominant protein, PDAC pancreatic ductal adenocarcinoma, HCC hepatocellular carcinoma, CRC colorectal cancer

alter CAF signals and effectors await further mechanistic and functional investigation.

\section{Conclusions}

Fibroblasts have been ignored over decades despite their abundance in the tumor stroma. The pivotal role of CAFs has now emerged in the fields of cancer biology and achieved wide attention. Obviously targeting CAFs or their secretome provides us an effective way to overcome cancers by reducing the immunosuppressive events and remodeling TME but not killing cancer cells directly. Thus, the checkpoint blockade immunotherapies, together with the development of CAF-targeted therapies, hold promise for the treatment of a prevalent tumor that thrives in a fibroblast-rich environment.

However, several challenges must be overcome in order to expedite the leap from bench to bedside. First, the original sources of CAFs in different cancer types remain elusive. Second, due to the original and functional heterogeneity of CAFs, which CAF subtypes populate the immunosuppression TME? Thirdly, are CAF subtypes with distinct phenotypes and immune functions originated from different cellular sources? Finally, the concept that CAF-specific secretome regulates antitumor immune response primarily bases on in vitro studies. Therefore, to help accelerate the integration of CAF study into clinical care, future genetic fate mapping and single-cell transcriptional analysis are encourage, which could offer new insights into the heterogeneity, hierarchy, and plasticity of CAFs. Last but not least, we should also carefully consider the in vivo models in order to precisely characterize the function of CAF-released factors that modulate tumor immunity.

\section{Abbreviations}

APC: Antigen-presenting cell; Arg: Arginase; CAFs: Cancer-associated fibroblasts; CAR: Chimeric antigen receptor; CCL2: Chemokine ligand 2; CXCL12: CX-chemokine ligand 12; CXCL14: CX-chemokine ligand 14; DC: Dendritic cell; ECM: Extracellular matrix; EMT: Epithelial-to-mesenchymal transition; EndMT: Endothelial-to-mesenchymal transition; FAP: Fibroblast activation protein; FASL: FAS ligand; IDO: Indoleamine-2,3-dioxygenase; IL13: Interleukin-13; IL-6: Interleukin-6; IL-8: Interleukin-8; M-CSF: Macrophage colony-stimulating factor; MDSC: Myeloid-derived suppressor cell; MMPs: Matrix metalloproteinases; MSCs: Mesenchymal stem cells; NK: Natural killer cells; PDGFR: Platelet-derived growth factor; PD-L1/2: Programmed cell death 1 ligand 1/2; PDPN: Podoplanin; S100A4: Fibroblast-specific protein-1; TAMs: Tumor-associated macrophages; TGF- $\beta$ : Transforming growth factor- $\beta$; $\mathrm{T}_{H}$ cells: $\mathrm{CD}^{+}$helper lymphocytes; TME: Tumor microenvironment; Tregs: Regulatory T cell; VEGF: Vascular endothelial growth factor A; aSMA: a-Smooth muscle actin

\section{Acknowledgements}

Not applicable.

\section{Authors' contributions}

TYL wrote the manuscript. CCH prepared all the figures and table. SWW was involved in the revising of the manuscript. PQF and ZFM contributed to the manuscript preparation. RY and LX participated in the design of the manuscript and the revision. All authors read and approved the final manuscript. 


\section{Funding}

This work was supported by the National Natural Science Foundation of China $(81802277,81872378)$ and China Postdoctoral Science Foundation (2018 M642198), Project of Jiangsu Provincial Medical Talent (ZDRCA2016033).

\section{Availability of data and materials}

All data generated during this study are included in this published article.

\section{Ethics approval and consent to participate}

Not applicable.

\section{Consent for publication}

All authors reviewed and approved the manuscript.

\section{Competing interests}

The authors declare that they have no competing interests.

\section{Author details}

'Department of Thoracic Surgery, Jiangsu Cancer Hospital \& Jiangsu Institute of Cancer Research \& The Affiliated Cancer Hospital of Nanjing Medical University, Jiangsu Key Laboratory of Molecular and Translational Cancer Research, Collaborative Innovation Center for Cancer Personalized Medicine, Nanjing, China. ${ }^{2}$ The Fourth Clinical College of Nanjing Medical University, Nanjing, China. ${ }^{3}$ Department of Scientific Research, Jiangsu Cancer Hospital \& Jiangsu Institute of Cancer Research \& The Affiliated Cancer Hospital of Nanjing Medical University, Jiangsu Key Laboratory of Molecular and Translational Cancer Research, Nanjing, China. ${ }^{4}$ Jiangsu Biobank of Clinical Resources, Nanjing 210009, China. ${ }^{5}$ Department of Clinical Pharmacy, School of Basic Medical Sciences and Clinical Pharmacy, China Pharmaceutical University, Nanjing 210009, China.

\section{Received: 15 June 2019 Accepted: 12 August 2019}

\section{1.}

\section{References}

1. Altorki NK, Markowitz GJ, Gao D, Port JL, Saxena A, Stiles B, McGraw T, Mittal $\checkmark$. The lung microenvironment: an important regulator of tumour growth and metastasis. Nat Rev Cancer. 2019;19:9-31.

2. Quail DF, Joyce JA. Microenvironmental regulation of tumor progression and metastasis. Nat Med. 2013;19:1423-37.

3. Maman S, Witz IP. A history of exploring cancer in context. Nat Rev Cancer. 2018;18:359-76.

4. Zhuang $X$, Zhang $H$, Hu G. Cancer and microenvironment plasticity: doubleedged swords in metastasis. Trends Pharmacol Sci. 2019.

5. Turley SJ, Cremasco V, Astarita JL. Immunological hallmarks of stromal cells in the tumour microenvironment. Nat Rev Immunol. 2015;15:669-82.

6. Kalluri R. The biology and function of fibroblasts in cancer. Nat Rev Cancer 2016:16:582-98.

7. Chen X, Song E. Turning foes to friends: targeting cancer-associated fibroblasts. Nat Rev Drug Discov. 2019;18:99-115.

8. Ziani L, Chouaib S, Thiery J. Alteration of the antitumor immune response by cancer-associated fibroblasts. Front Immunol. 2018;9:414.

9. Lambrechts D, Wauters E, Boeckx B, Aibar S, Nittner D, Burton O, Bassez A, Decaluwe H, Pircher A, Van den Eynde K, et al. Phenotype molding of stromal cells in the lung tumor microenvironment. Nat Med. 2018;24 1277-89.

10. Kobayashi H, Enomoto A, Woods SL, Burt AD, Takahashi M, Worthley DL. Cancer-associated fibroblasts in gastrointestinal cancer. Nat Rev Gastroenterol Hepatol. 2019;16:282-95.

11. Ohlund D, Elyada E, Tuveson D. Fibroblast heterogeneity in the cancer wound. J Exp Med. 2014;211:1503-23.

12. Wang C, Yin R, Dai J, Gu Y, Cui S, Ma H, Zhang Z, Huang J, Qin N, Jiang T, et al. Whole-genome sequencing reveals genomic signatures associated with the inflammatory microenvironments in Chinese NSCLC patients. Nat Commun. 2018:9:2054.

13. De Wever O, Demetter P, Mareel M, Bracke M. Stromal myofibroblasts are drivers of invasive cancer growth. Int J Cancer. 2008:123:2229-38.

14. Ahmadzadeh M, Rosenberg SA. TGF-beta 1 attenuates the acquisition and expression of effector function by tumor antigen-specific human memory CD8 T cells. J Immunol. 2005;174:5215-23.
15. Feig C, Jones JO, Kraman M, Wells RJ, Deonarine A, Chan DS, Connell CM, Roberts EW, Zhao Q, Caballero OL, et al. Targeting CXCL12 from FAPexpressing carcinoma-associated fibroblasts synergizes with anti-PD-L1 immunotherapy in pancreatic cancer. Proc Natl Acad Sci U S A. 2013;110: 20212-7.

16. Kojima Y, Acar A, Eaton EN, Mellody KT, Scheel C, Ben-Porath I, Onder TT, Wang ZC, Richardson AL, Weinberg RA, Orimo A. Autocrine TGF-beta and stromal cell-derived factor-1 (SDF-1) signaling drives the evolution of tumorpromoting mammary stromal myofibroblasts. Proc Natl Acad Sci U S A. 2010;107:20009-14.

17. Vicent S, Sayles LC, Vaka D, Khatri P, Gevaert O, Chen R, Zheng Y, Gillespie AK, Clarke N, Xu Y, et al. Cross-species functional analysis of cancerassociated fibroblasts identifies a critical role for CLCF1 and IL-6 in nonsmall cell lung cancer in vivo. Cancer Res. 2012;72:5744-56.

18. Lohr M, Schmidt C, Ringel J, Kluth M, Muller P, Nizze H, Jesnowski R Transforming growth factor-beta1 induces desmoplasia in an experimental model of human pancreatic carcinoma. Cancer Res. 2001:61:550-5.

19. Aoyagi Y, Oda T, Kinoshita T, Nakahashi C, Hasebe T, Ohkohchi N, Ochiai A. Overexpression of TGF-beta by infiltrated granulocytes correlates with the expression of collagen mRNA in pancreatic cancer. Br J Cancer. 2004;91: 1316-26.

20. Erez N, Truitt M, Olson P, Arron ST, Hanahan D. Cancer-associated fibroblasts are activated in incipient neoplasia to orchestrate tumor-promoting inflammation in an NF-kappaB-dependent manner. Cancer Cell. 2010;17:135-47.

21. Omary MB, Lugea A, Lowe AW, Pandol SJ. The pancreatic stellate cell: a star on the rise in pancreatic diseases. J Clin Invest. 2007:117:50-9.

22. Yin C, Evason KJ, Asahina K, Stainier DY. Hepatic stellate cells in liver development, regeneration, and cancer. J Clin Invest. 2013;123:1902-10.

23. Fischer KR, Durrans A, Lee S, Sheng J, Li F, Wong ST, Choi H, El Rayes T, Ryu $\mathrm{S}$, Troeger J, et al. Epithelial-to-mesenchymal transition is not required for lung metastasis but contributes to chemoresistance. Nature. 2015;527:472-6.

24. Rhim AD, Mirek ET, Aiello NM, Maitra A, Bailey JM, McAllister F, Reichert M, Beatty GL, Rustgi AK, Vonderheide $\mathrm{RH}$, et al. EMT and dissemination precede pancreatic tumor formation. Cell. 2012:148:349-61.

25. Potenta S, Zeisberg E, Kalluri R. The role of endothelial-to-mesenchymal transition in cancer progression. Br J Cancer. 2008:99:1375-9.

26. Jotzu C, Alt E, Welte G, Li J, Hennessy BT, Devarajan E, Krishnappa S, Pinilla $\mathrm{S}$, Droll L, Song YH. Adipose tissue derived stem cells differentiate into carcinoma-associated fibroblast-like cells under the influence of tumor derived factors. Cell Oncol (Dordr). 2011;34:55-67.

27. Dulauroy S, Di Carlo SE, Langa F, Eberl G, Peduto L. Lineage tracing and genetic ablation of ADAM12(+) perivascular cells identify a major source of profibrotic cells during acute tissue injury. Nat Med. 2012;18:1262-70.

28. Wikstrom P, Marusic J, Stattin P, Bergh A. Low stroma androgen receptor level in normal and tumor prostate tissue is related to poor outcome in prostate cancer patients. Prostate. 2009;69:799-809.

29. Iwano M, Plieth D, Danoff TM, Xue C, Okada H, Neilson EG. Evidence that fibroblasts derive from epithelium during tissue fibrosis. J Clin Invest. 2002; 110:341-50.

30. Zeisberg EM, Potenta S, Xie L, Zeisberg M, Kalluri R. Discovery of endothelial to mesenchymal transition as a source for carcinoma-associated fibroblasts. Cancer Res. 2007:67:10123-8.

31. Barth PJ, Ebrahimsade S, Ramaswamy A, Moll R. CD34+ fibrocytes in invasive ductal carcinoma, ductal carcinoma in situ, and benign breast lesions. Virchows Arch. 2002:440:298-303.

32. Jung Y, Kim JK, Shiozawa Y, Wang J, Mishra A, Joseph J, Berry JE, McGee S, Lee $E$, Sun $H$, et al. Recruitment of mesenchymal stem cells into prostate tumours promotes metastasis. Nat Commun. 2013;4:1795

33. Zhu Q, Zhang X, Zhang L, Li W, Wu H, Yuan X, Mao F, Wang M, Zhu W, Qian H, Xu W. The IL-6-STAT3 axis mediates a reciprocal crosstalk between cancer-derived mesenchymal stem cells and neutrophils to synergistically prompt gastric cancer progression. Cell Death Dis. 2014;5:e1295.

34. Weber CE, Kothari AN, Wai PY, Li NY, Driver J, Zapf MA, Franzen CA, Gupta GN, Osipo C, Zlobin A, et al. Osteopontin mediates an MZF1-TGF-beta1dependent transformation of mesenchymal stem cells into cancerassociated fibroblasts in breast cancer. Oncogene. 2015:34:4821-33.

35. Hosein AN, Wu M, Arcand SL, Lavallee S, Hebert J, Tonin PN, Basik M. Breast carcinoma-associated fibroblasts rarely contain p53 mutations or chromosomal aberrations. Cancer Res. 2010;70:5770-7.

36. Li P, Shan JX, Chen XH, Zhang D, Su LP, Huang XY, Yu BQ, Zhi QM, Li CL, Wang YQ, et al. Epigenetic silencing of microRNA-149 in cancer-associated 
fibroblasts mediates prostaglandin E2/interleukin-6 signaling in the tumor microenvironment. Cell Res. 2015;25:588-603.

37. Vizoso M, Puig M, Carmona FJ, Maqueda M, Velasquez A, Gomez A, Labernadie A, Lugo R, Gabasa M, Rigat-Brugarolas LG, et al. Aberrant DNA methylation in non-small cell lung cancer-associated fibroblasts. Carcinogenesis. 2015;36:1453-63.

38. Albrengues J, Bertero T, Grasset E, Bonan S, Maiel M, Bourget I, Philippe C, Herraiz Serrano C, Benamar S, Croce O, et al. Epigenetic switch drives the conversion of fibroblasts into proinvasive cancer-associated fibroblasts. Nat Commun. 2015;6:10204.

39. Ohlund D, Handly-Santana A, Biffi G, Elyada E, Almeida AS, Ponz-Sarvise M, Corbo V, Oni TE, Hearn SA, Lee EJ, et al. Distinct populations of inflammatory fibroblasts and myofibroblasts in pancreatic cancer. J Exp Med. 2017;214:579-96.

40. Lynch MD, Watt FM. Fibroblast heterogeneity: implications for human disease. J Clin Invest. 2018;128:26-35.

41. Zhang J, Chen L, Liu X, Kammertoens T, Blankenstein T, Qin Z. Fibroblastspecific protein 1/S100A4-positive cells prevent carcinoma through collagen production and encapsulation of carcinogens. Cancer Res. 2013;73:2770-81.

42. Arnold JN, Magiera L, Kraman M, Fearon DT. Tumoral immune suppression by macrophages expressing fibroblast activation protein-alpha and heme oxygenase-1. Cancer Immunol Res. 2014;2:121-6.

43. Augsten M. Cancer-associated fibroblasts as another polarized cell type of the tumor microenvironment. Front Oncol. 2014;4:62.

44. Su S, Chen J, Yao H, Liu J, Yu S, Lao L, Wang M, Luo M, Xing Y, Chen F, et al. CD10(+)GPR77(+) Cancer-associated fibroblasts promote cancer formation and chemoresistance by sustaining cancer stemness. Cell. 2018;172:841-56 e816.

45. Givel AM, Kieffer Y, Scholer-Dahirel A, Sirven P, Cardon M, Pelon F, Magagna I, Gentric G, Costa A. Bonneau C, et al: miR200-regulated CXCL12beta promotes fibroblast heterogeneity and immunosuppression in ovarian cancers. Nat Commun. 2018;9:1056.

46. Costa A, Kieffer Y, Scholer-Dahirel A, Pelon F, Bourachot B, Cardon M, Sirven P, Magagna I, Fuhrmann L, Bernard C, et al. Fibroblast heterogeneity and immunosuppressive environment in human breast cancer. Cancer Cell. 2018;33:463-79 e410.

47. Li H, Courtois ET, Sengupta D, Tan Y, Chen KH, Goh JJL, Kong SL, Chua C, Hon LK, Tan WS, et al. Reference component analysis of single-cell transcriptomes elucidates cellular heterogeneity in human colorectal tumors. Nat Genet. 2017:49:708-18.

48. Bartoschek M, Oskolkov N, Bocci M, Lovrot J, Larsson C, Sommarin M, Madsen CD, Lindgren D, Pekar G, Karlsson G, et al. Spatially and functionally distinct subclasses of breast cancer-associated fibroblasts revealed by single cell RNA sequencing. Nat Commun. 2018;9:5150.

49. Orimo A, Gupta PB, Sgroi DC, Arenzana-Seisdedos F, Delaunay T, Naeem R, Carey VJ, Richardson AL, Weinberg RA. Stromal fibroblasts present in invasive human breast carcinomas promote tumor growth and angiogenesis through elevated SDF-1/CXCL12 secretion. Cell. 2005;121:335-48.

50. Yamamura Y, Asai N, Enomoto A, Kato T, Mii S, Kondo Y, Ushida K, Niimi K, Tsunoda N, Nagino M, et al. Akt-Girdin signaling in cancer-associated fibroblasts contributes to tumor progression. Cancer Res. 2015;75:813-23.

51. Labernadie A, Kato T, Bruques A, Serra-Picamal X, Derzsi S, Arwert E, Weston A, Gonzalez-Tarrago V, Elosegui-Artola A, Albertazzi L, et al. A mechanically active heterotypic E-cadherin/N-cadherin adhesion enables fibroblasts to drive cancer cell invasion. Nat Cell Biol. 2017;19:224-37.

52. Ozdemir BC, Pentcheva-Hoang T, Carstens JL, Zheng X, Wu CC, Simpson TR, Laklai H, Sugimoto H, Kahlert C, Novitskiy SV, et al. Depletion of carcinoma-associated fibroblasts and fibrosis induces immunosuppression and accelerates pancreas cancer with reduced survival. Cancer Cell. 2014;25:719-34.

53. Rhim AD, Oberstein PE, Thomas DH, Mirek ET, Palermo CF, Sastra SA, Dekleva EN, Saunders T, Becerra CP, Tattersall IW, et al. Stromal elements act to restrain, rather than support, pancreatic ductal adenocarcinoma. Cancer Cell. 2014;25:735-47.

54. Brechbuhl HM, Finlay-Schultz J, Yamamoto TM, Gillen AE, Cittelly DM, Tan AC, Sams SB, Pillai MM, Elias AD, Robinson WA, et al. Fibroblast subtypes regulate responsiveness of luminal breast cancer to estrogen. Clin Cancer Res. 2017;23:1710-21.

55. Mace TA, Ameen Z, Collins A, Wojcik S, Mair M, Young GS, Fuchs JR, Eubank TD, Frankel WL, Bekaii-Saab T, et al. Pancreatic cancer-associated stellate cells promote differentiation of myeloid-derived suppressor cells in a STAT3dependent manner. Cancer Res. 2013;73:3007-18.
56. Nagarsheth N, Wicha MS, Zou W. Chemokines in the cancer microenvironment and their relevance in cancer immunotherapy. Nat Rev Immunol. 2017;17:559-72.

57. Zhang R, Qi F, Zhao F, Li G, Shao S, Zhang X, Yuan L, Feng Y. Cancerassociated fibroblasts enhance tumor-associated macrophages enrichment and suppress NK cells function in colorectal cancer. Cell Death Dis. 2019;10:273.

58. Ueshima E, Fujimori M, Kodama H, Felsen D, Chen J, Durack JC, Solomon SB, Coleman JA, Srimathveeravalli G. Macrophage secreted TGF-beta1 contributes to fibroblast activation and ureteral stricture following ablation injury. Am J Physiol Renal Physiol. 2019.

59. Takahashi H, Sakakura K, Kudo T, Toyoda M, Kaira K, Oyama T, Chikamatsu K. Cancer-associated fibroblasts promote an immunosuppressive microenvironment through the induction and accumulation of protumoral macrophages. Oncotarget. 2017;8:8633-47.

60. Higashino N, Koma YI, Hosono M, Takase N, Okamoto M, Kodaira H, Nishio M, Shigeoka M, Kakeji Y, Yokozaki H. Fibroblast activation protein-positive fibroblasts promote tumor progression through secretion of CCL2 and interleukin-6 in esophageal squamous cell carcinoma. Lab Invest. 2019.

61. Fujii N, Shomori K, Shiomi T, Nakabayashi M, Takeda C, Ryoke K, Ito H. Cancer-associated fibroblasts and CD163-positive macrophages in oral squamous cell carcinoma: their clinicopathological and prognostic significance. J Oral Pathol Med. 2012;41:444-51.

62. Herrera M, Herrera A, Dominguez G, Silva J, Garcia V, Garcia JM, Gomez I, Soldevilla B, Munoz C, Provencio M, et al. Cancer-associated fibroblast and M2 macrophage markers together predict outcome in colorectal cancer patients. Cancer Sci. 2013;104:437-44.

63. Cheng Y, Li H, Deng Y, Tai Y, Zeng K, Zhang Y, Liu W, Zhang Q, Yang Y. Cancer-associated fibroblasts induce PDL1+ neutrophils through the IL6STAT3 pathway that foster immune suppression in hepatocellular carcinoma. Cell Death Dis. 2018;9:422.

64. Ma Y, Hwang RF, Logsdon CD, Ullrich SE. Dynamic mast cell-stromal cell interactions promote growth of pancreatic cancer. Cancer Res. 2013;73: 3927-37.

65. Varricchi G, Galdiero MR, Loffredo S, Marone G, lannone R, Marone G, Granata F. Are Mast Cells MASTers in Cancer? Front Immunol. 2017:8:424.

66. Allard B, Beavis PA, Darcy PK, Stagg J. Immunosuppressive activities of adenosine in cancer. Curr Opin Pharmacol. 2016;29:7-16.

67. Danelli L, Frossi B, Pucillo CE. Mast cell/MDSC a liaison immunosuppressive for tumor microenvironment. Oncoimmunology. 2015;4:e1001232.

68. Batlle E, Massague J. Transforming growth factor-beta signaling in immunity and cancer. Immunity. 2019;50:924-40.

69. Donatelli SS, Zhou JM, Gilvary DL, Eksioglu EA, Chen X, Cress WD, Haura EB, Schabath MB, Coppola D, Wei S, Djeu JY. TGF-beta-inducible microRNA-183 silences tumor-associated natural killer cells. Proc Natl Acad Sci U S A. 2014; 111:4203-8.

70. Flavell RA, Sanjabi S, Wrzesinski SH, Licona-Limon P. The polarization of immune cells in the tumour environment by TGFbeta. Nat Rev Immunol. 2010;10:554-67.

71. Kitamura H, Kamon H, Sawa S, Park SJ, Katunuma N, Ishihara K, Murakami M, Hirano T. IL-6-STAT3 controls intracellular MHC class II alphabeta dimer level through cathepsin S activity in dendritic cells. Immunity. 2005;23:491-502.

72. Kitamura H, Ohno Y, Toyoshima Y, Ohtake J, Homma S, Kawamura H, Takahashi N, Taketomi A. Interleukin-6/STAT3 signaling as a promising target to improve the efficacy of cancer immunotherapy. Cancer Sci. 2017; 108:1947-52.

73. Chomarat P, Banchereau J, Davoust J, Palucka AK. IL-6 switches the differentiation of monocytes from dendritic cells to macrophages. Nat Immunol. 2000;1:510-4.

74. Gabrilovich DI, Chen HL, Girgis KR, Cunningham HT, Meny GM, Nadaf S, Kavanaugh D, Carbone DP. Production of vascular endothelial growth factor by human tumors inhibits the functional maturation of dendritic cells. Nat Med. 1996;2:1096-103.

75. Dikov MM, Ohm JE, Ray N, Tchekneva EE, Burlison J, Moghanaki D, Nadaf S, Carbone DP. Differential roles of vascular endothelial growth factor receptors 1 and 2 in dendritic cell differentiation. J Immunol. 2005;174:215-22.

76. Thomas DA, Massague J. TGF-beta directly targets cytotoxic T cell functions during tumor evasion of immune surveillance. Cancer Cell. 2005;8:369-80.

77. E-O A. AJ C, J W, J W, R F, JC R, JF M, J C-A, C C, JG G, et al: Activated pancreatic stellate cells sequester $\mathrm{CD} 8+\mathrm{T}$ cells to reduce their infiltration of 
the juxtatumoral compartment of pancreatic ductal adenocarcinoma. Gastroenterology. 2013;145:1121-32.

78. Takahashi H, Sakakura K, Kawabata-Iwakawa R, Rokudai S, Toyoda M, Nishiyama M, Chikamatsu K. Immunosuppressive activity of cancer-associated fibroblasts in head and neck squamous cell carcinoma. Cancer Immunol Immunother. 2015:64:1407-17.

79. Ino Y, Yamazaki-Itoh R, Oguro S, Shimada K, Kosuge T, Zavada J, Kanai Y, Hiraoka N. Arginase II expressed in cancer-associated fibroblasts indicates tissue hypoxia and predicts poor outcome in patients with pancreatic cancer. PLoS One. 2013;8:e55146.

80. Rabinovich GA, Toscano MA. Turning 'sweet' on immunity: galectin-glycan interactions in immune tolerance and inflammation. Nat Rev Immunol. 2009;9:338-52.

81. Valach J, Fik Z, Strnad H, Chovanec M, Plzak J, Cada Z, Szabo P, Sachova J, Hroudova M, Urbanova M, et al. Smooth muscle actin-expressing stromal fibroblasts in head and neck squamous cell carcinoma: increased expression of galectin-1 and induction of poor prognosis factors. Int J Cancer. 2012; 131:2499-508

82. De Monte L, Reni M, Tassi E, Clavenna D, Papa I, Recalde H, Braga M, Di Carlo V, Doglioni C, Protti MP. Intratumor T helper type 2 cell infiltrate correlates with cancer-associated fibroblast thymic stromal lymphopoietin production and reduced survival in pancreatic cancer. J Exp Med. 2011;208:469-78.

83. Kinoshita T, Ishii G, Hiraoka N, Hirayama S, Yamauchi C, Aokage K, Hishida T, Yoshida J, Nagai K, Ochiai A. Forkhead box P3 regulatory T cells coexisting with cancer associated fibroblasts are correlated with a poor outcome in lung adenocarcinoma. Cancer Sci. 2013;104:409-15.

84. Chen W, Jin W, Hardegen N, Lei KJ, Li L, Marinos N, McGrady G, Wahl SM. Conversion of peripheral CD4+CD25- naive T cells to CD4+CD25+ regulatory $T$ cells by TGF-beta induction of transcription factor Foxp3. J Exp Med. 2003;198:1875-86.

85. Gutcher I, Donkor MK, Ma Q, Rudensky AY, Flavell RA, Li MO. Autocrine transforming growth factor-beta1 promotes in vivo Th17 cell differentiation. Immunity. 2011;34:396-408.

86. Deng Y, Cheng J, Fu B, Liu W, Chen G, Zhang Q, Yang Y. Hepatic carcinoma-associated fibroblasts enhance immune suppression by facilitating the generation of myeloid-derived suppressor cells. Oncogene. 2017:36:1090-101.

87. Khalili JS, Liu S, Rodriguez-Cruz TG, Whittington M, Wardell S, Liu C, Zhang M, Cooper ZA, Frederick DT, Li Y, et al. Oncogenic BRAF(V600E) promotes stromal cell-mediated immunosuppression via induction of interleukin-1 in melanoma. Clin Cancer Res. 2012;18:5329-40.

88. Nazareth MR, Broderick L, Simpson-Abelson MR, Kelleher RJ Jr, Yokota SJ, Bankert RB. Characterization of human lung tumor-associated fibroblasts and their ability to modulate the activation of tumor-associated T cells. J Immunol. 2007:178:5552-62.

89. Pinchuk IV, Saada JI, Beswick EJ, Boya G, Qiu SM, Mifflin RC, Raju GS, Reyes VE, Powell DW. PD-1 ligand expression by human colonic myofibroblasts/ fibroblasts regulates CD4+ T-cell activity. Gastroenterology. 2008;135:1228371237 e1221-1222

90. Li Z, Zhou J, Zhang J, Li S, Wang H, Du J. Cancer-associated fibroblasts promote PD-L1 expression in mice cancer cells via secreting CXCL5. Int J Cancer. 2019.

91. Harper J, Sainson RC. Regulation of the anti-tumour immune response by cancer-associated fibroblasts. Semin Cancer Biol. 2014;25:69-77.

92. Augsten $M$, Sjoberg E, Frings O, Vorrink SU, Frijhoff J, Olsson E, Borg A, Ostman A. Cancer-associated fibroblasts expressing CXCL14 rely upon NOS1-derived nitric oxide signaling for their tumor-supporting properties. Cancer Res. 2014:74:2999-3010.

93. Joyce JA, Fearon DT. T cell exclusion, immune privilege, and the tumor microenvironment. Science. 2015:348:74-80.

94. Sorokin L. The impact of the extracellular matrix on inflammation. Nat Rev Immunol. 2010;10:712-23.

95. Acerbi I, Cassereau L, Dean I, Shi Q, Au A, Park C, Chen YY, Liphardt J, Hwang ES, Weaver VM. Human breast cancer invasion and aggression correlates with ECM stiffening and immune cell infiltration. Integr Biol (Camb). 2015;7:1120-34.

96. McWhorter FY, Wang T, Nguyen P, Chung T, Liu WF. Modulation of macrophage phenotype by cell shape. Proc Natl Acad Sci U S A. 2013;110: 17253-8.

97. Alkasalias T, Moyano-Galceran L, Arsenian-Henriksson M, Lehti K. Fibroblasts in the tumor microenvironment: shield or spear? Int J Mol Sci. 2018;19.
98. Chakravarthy A, Khan L, Bensler NP, Bose P, De Carvalho DD. TGF-betaassociated extracellular matrix genes link cancer-associated fibroblasts to immune evasion and immunotherapy failure. Nat Commun. 2018;9:4692.

99. Calvo F, Ege N, Grande-Garcia A, Hooper S, Jenkins RP, Chaudhry SI, Harrington K, Williamson P, Moeendarbary E, Charras G, Sahai E. Mechanotransduction and YAP-dependent matrix remodelling is required for the generation and maintenance of cancer-associated fibroblasts. Nat Cell Biol. 2013;15:637-46.

100. Qian L, Tang Z, Yin S, Mo F, Yang X, Hou X, Liu A, Lu X. Fusion of dendritic cells and cancer-associated fibroblasts for activation of anti-tumor cytotoxic T lymphocytes. J Biomed Nanotechnol. 2018;14:1826-35.

101. Yang $X$, Lin Y, Shi Y, Li B, Liu W, Yin W, Dang Y, Chu Y, Fan J, He R. FAP promotes immunosuppression by cancer-associated fibroblasts in the tumor microenvironment via STAT3-CCL2 signaling. Cancer Res. 2016;76:4124-35.

102. Kumar V, Donthireddy L, Marvel D, Condamine T, Wang F, Lavilla-Alonso S, Hashimoto A, Vonteddu P, Behera R, Goins MA, et al. Cancer-associated fibroblasts neutralize the anti-tumor effect of CSF1 receptor blockade by inducing PMN-MDSC infiltration of tumors. Cancer Cell. 2017;32:654-68 e655.

103. Li T, Yi S, Liu W, Jia C, Wang G, Hua X, Tai Y, Zhang Q, Chen G. Colorectal carcinoma-derived fibroblasts modulate natural killer cell phenotype and antitumor cytotoxicity. Med Oncol. 2013;30:663.

104. Duperret EK, Trautz A, Ammons D, Perales-Puchalt A, Wise MC, Yan J, Reed C, Weiner DB. Alteration of the tumor stroma using a consensus DNA vaccine targeting fibroblast activation protein (FAP) Synergizes with antitumor vaccine therapy in mice. Clin Cancer Res. 2018;24:1190-201.

105. Tan W, Zhang W, Strasner A, Grivennikov S, Cheng JQ, Hoffman RM, Karin M. Tumour-infiltrating regulatory $T$ cells stimulate mammary cancer metastasis through RANKL-RANK signalling. Nature. 2011;470:548-53.

106. Cremasco V, Astarita JL, Grauel AL, Keerthivasan S, Maclsaac K, Woodruff MC, Wu M, Spel L, Santoro S, Amoozgar Z, et al. FAP delineates heterogeneous and functionally divergent stromal cells in immune-excluded breast tumors. Cancer Immunol Res. 2018;6:1472-85.

107. Comito G, Iscaro A, Bacci M, Morandi A, Ippolito L, Parri M, Montagnani I, Raspollini MR, Serni S, Simeoni L, et al. Lactate modulates CD4(+) T-cell polarization and induces an immunosuppressive environment, which sustains prostate carcinoma progression via TLR8/miR21 axis. Oncogene. 2019:38:3681-95.

108. Sugimoto $H$, Mundel TM, Kieran MW, Kalluri R. Identification of fibroblast heterogeneity in the tumor microenvironment. Cancer Biol Ther. 2006;5: 1640-6.

109. Cohen N, Shani O, Raz Y, Sharon Y, Hoffman D, Abramovitz L, Erez N. Fibroblasts drive an immunosuppressive and growth-promoting microenvironment in breast cancer via secretion of Chitinase 3-like 1. Oncogene. 2017:36:4457-68.

110. Zhang J, Chen L, Xiao M, Wang C, Qin Z. FSP1+ fibroblasts promote skin carcinogenesis by maintaining MCP-1-mediated macrophage infiltration and chronic inflammation. Am J Pathol. 2011;178:382-90.

111. Lakins MA, Ghorani E, Munir H, Martins CP, Shields JD. Cancer-associated fibroblasts induce antigen-specific deletion of CD8 (+) T cells to protect tumour cells. Nat Commun. 2018;9:948.

112. Sakai T, Aokage K, Neri S, Nakamura H, Nomura S, Tane K, Miyoshi T, Sugano M, Kojima M, Fujii S, et al. Link between tumor-promoting fibrous microenvironment and an immunosuppressive microenvironment in stage I lung adenocarcinoma. Lung Cancer. 2018;126:64-71.

113. Jacobs J, Deschoolmeester V, Zwaenepoel K, Flieswasser T, Deben C, Van den Bossche J, Hermans C, Rolfo C, Peeters M, De Wever O, et al. Unveiling a CD70-positive subset of cancer-associated fibroblasts marked by promigratory activity and thriving regulatory $T$ cell accumulation. Oncoimmunology. 2018;7:e1440167.

114. Meisel R, Zibert A, Laryea M, Gobel U, Daubener W, Dilloo D. Human bone marrow stromal cells inhibit allogeneic T-cell responses by indoleamine 2,3dioxygenase-mediated tryptophan degradation. Blood. 2004;103:4619-21.

115. Kobayashi N, Miyoshi S, Mikami T, Koyama H, Kitazawa M, Takeoka M, Sano K, Amano J, Isogai Z, Niida S, et al. Hyaluronan deficiency in tumor stroma impairs macrophage trafficking and tumor neovascularization. Cancer Res. 2010;70:7073-83.

116. Kraman M, Bambrough PJ, Arnold JN, Roberts EW, Magiera L, Jones JO, Gopinathan A, Tuveson DA, Fearon DT. Suppression of antitumor immunity by stromal cells expressing fibroblast activation protein-alpha. Science. 2010; 330:827-30. 
117. Gunderson AJ, Yamazaki T, McCarty K, Phillips M, Alice A, Bambina S, Zebertavage L, Friedman D, Cottam B, Newell P, et al. Blockade of fibroblast activation protein in combination with radiation treatment in murine models of pancreatic adenocarcinoma. PLoS One. 2019:14:e0211117.

118. Loeffler M, Kruger JA, Niethammer AG, Reisfeld RA. Targeting tumorassociated fibroblasts improves cancer chemotherapy by increasing intratumoral drug uptake. J Clin Invest. 2006;116:1955-62.

119. Kakarla S, Chow KK, Mata M, Shaffer DR, Song XT, Wu MF, Liu H, Wang LL, Rowley DR, Pfizenmaier K, Gottschalk S. Antitumor effects of chimeric receptor engineered human T cells directed to tumor stroma. Mol Ther. 2013;21:1611-20

120. Wang LC, Lo A, Scholler J, Sun J, Majumdar RS, Kapoor V, Antzis M, Cotner CE, Johnson LA, Durham AC, et al. Targeting fibroblast activation protein in tumor stroma with chimeric antigen receptor T cells can inhibit tumor growth and augment host immunity without severe toxicity. Cancer Immunol Res. 2014;2:154-66.

121. Lo A, Wang LS, Scholler J, Monslow J, Avery D, Newick K, O'Brien S, Evans RA, Bajor DJ, Clendenin C, et al. Tumor-promoting desmoplasia is disrupted by depleting FAP-expressing stromal cells. Cancer Res. 2015;75:2800-10.

122. Freedman JD, Duffy MR, Lei-Rossmann J, Muntzer A, Scott EM, Hagel J, Campo L, Bryant RJ, Verrill C, Lambert A, et al. An oncolytic virus expressing a T-cell engager simultaneously targets cancer and immunosuppressive stromal cells. Cancer Res. 2018;78:6852-65.

123. de Sostoa J, Fajardo CA, Moreno R, Ramos MD, Farrera-Sal M, Alemany R. Targeting the tumor stroma with an oncolytic adenovirus secreting a fibroblast activation protein-targeted bispecific T-cell engager. J Immunother Cancer. 2019;7:19.

124. Roberts EW, Deonarine A, Jones JO, Denton AE, Feig C, Lyons SK, Espeli M, Kraman M, McKenna B, Wells RJ, et al. Depletion of stromal cells expressing fibroblast activation protein-alpha from skeletal muscle and bone marrow results in cachexia and anemia. J Exp Med. 2013;210:1137-51.

125. Murakami M, Ernsting MJ, Undzys E, Holwell N, Foltz WD, Li SD. Docetaxel conjugate nanoparticles that target alpha-smooth muscle actin-expressing stromal cells suppress breast cancer metastasis. Cancer Res. 2013;73:4862-71.

126. Ozdemir BC, Pentcheva-Hoang T, Carstens JL, Zheng X, Wu CC, Simpson TR, Laklai H, Sugimoto H, Kahlert C, Novitskiy SV, et al. Depletion of carcinomaassociated fibroblasts and fibrosis induces immunosuppression and accelerates pancreas cancer with reduced survival. Cancer Cell. 2015;28:831-3.

127. Zalcman G, Mazieres J, Margery J, Greillier L, Audigier-Valette C, Moro-Sibilot D, Molinier O, Corre R, Monnet I, Gounant V, et al. Bevacizumab for newly diagnosed pleural mesothelioma in the Mesothelioma Avastin Cisplatin Pemetrexed Study (MAPS): a randomised, controlled, open-label, phase 3 trial. Lancet. 2016:387:1405-14.

128. Sherman MH, Yu RT, Engle DD, Ding N, Atkins AR, Tiriac H, Collisson EA, Connor F, Van Dyke T, Kozlov S, et al. Vitamin D receptor-mediated stromal reprogramming suppresses pancreatitis and enhances pancreatic cancer therapy. Cell. 2014;159:80-93.

129. Ferrer-Mayorga G, Gomez-Lopez G, Barbachano A, Fernandez-Barral A, Pena C, Pisano DG, Cantero R, Rojo F, Munoz A, Larriba MJ. Vitamin D receptor expression and associated gene signature in tumour stromal fibroblasts predict clinical outcome in colorectal cancer. Gut. 2017:66:1449-62.

130. Froeling FE, Feig C, Chelala C, Dobson R, Mein CE, Tuveson DA, Clevers H, Hart IR, Kocher HM. Retinoic acid-induced pancreatic stellate cell quiescence reduces paracrine Wnt-beta-catenin signaling to slow tumor progression. Gastroenterology. 2011;141:1486-97 1497 e1481-1414.

131. Ene-Obong A, Clear AJ, Watt J, Wang J, Fatah R, Riches JC, Marshall JF, ChinAleong J, Chelala C, Gribben JG, et al. Activated pancreatic stellate cells sequester CD8+ T cells to reduce their infiltration of the juxtatumoral compartment of pancreatic ductal adenocarcinoma. Gastroenterology. 2013; 145:1121-32.

132. Ishihara S, Inman DR, Li WJ, Ponik SM, Keely PJ. Mechano-signal transduction in mesenchymal stem cells induces prosaposin secretion to drive the proliferation of breast cancer cells. Cancer Res. 2017;77:6179-89.

133. Gascard P, Tlsty TD. Carcinoma-associated fibroblasts: orchestrating the composition of malignancy. Genes Dev. 2016;30:1002-19.

134. Johnson DE, O'Keefe RA, Grandis JR. Targeting the IL-6/JAK/STAT3 signalling axis in cancer. Nat Rev Clin Oncol. 2018;15:234-48.

135. Mariathasan S, Turley SJ, Nickles D, Castiglioni A, Yuen K, Wang Y, Kadel EE III, Koeppen H, Astarita $J$, Cubas R, et al. TGFbeta attenuates tumour response to PD-L1 blockade by contributing to exclusion of T cells. Nature. 2018;554:544-8
136. Wei Y, Kim TJ, Peng DH, Duan D, Gibbons DL, Yamauchi M, Jackson JR, Le SauX CJ, Calhoun C, Peters J, et al. Fibroblast-specific inhibition of TGF-beta1 signaling attenuates lung and tumor fibrosis. J Clin Invest. 2017;127:3675-88.

137. Ohshio Y, Teramoto K, Hanaoka J, Tezuka N, Itoh Y, Asai T, Daigo Y, Ogasawara K. Cancer-associated fibroblast-targeted strategy enhances antitumor immune responses in dendritic cell-based vaccine. Cancer Sci. 2015;106:134-42.

138. Olive KP, Jacobetz MA, Davidson CJ, Gopinathan A, McIntyre D, Honess D, Madhu B, Goldgraben MA, Caldwell ME, Allard D, et al. Inhibition of Hedgehog signaling enhances delivery of chemotherapy in a mouse model of pancreatic cancer. Science. 2009;324:1457-61.

139. Reardon DA, Akabani G, Coleman RE, Friedman AH, Friedman HS, Herndon JE 2nd, McLendon RE, Pegram CN, Provenzale JM, Quinn JA, et al. Salvage radioimmunotherapy with murine iodine-131-labeled antitenascin monoclonal antibody 81C6 for patients with recurrent primary and metastatic malignant brain tumors: phase II study results. J Clin Oncol. 2006; 24:115-22.

\section{Publisher's Note}

Springer Nature remains neutral with regard to jurisdictional claims in published maps and institutional affiliations.
Ready to submit your research? Choose BMC and benefit from:

- fast, convenient online submission

- thorough peer review by experienced researchers in your field

- rapid publication on acceptance

- support for research data, including large and complex data types

- gold Open Access which fosters wider collaboration and increased citations

- maximum visibility for your research: over $100 \mathrm{M}$ website views per year

At $\mathrm{BMC}$, research is always in progress.

Learn more biomedcentral.com/submissions 